\title{
František Xaver Hodač jako spolutvůrce norem pracovního práva mezinárodní povahy v letech 1919-1924
}

\author{
Jiří Šouša jr.
}

Právnická fakulta, Univerzita Karlova

Kontaktni e-mail:sousaj@prf.cuni.cz

\section{František Xaver Hodač as a Co-Author of International Labor Law Rules Between Years 1919-1924}

\begin{abstract}
:
The article describes the work of František Xaver Hodač, a prominent Czechoslovak politician and representative of employers in the International Labor Organization in years 1919-1924. It deals with the activities of the International Labor Organization in the first five years of the existence of this professional organization based on the principle of tripartism and it monitors the participation of František Xaver Hodač therein. The article indicates that the Czechoslovak Republic played a significant role in creating the rudiments of modern labor law and in building the roots for international consensual dispute resolution. It tries to affect not only organizational and normative aspects, but also non-legal influences and the importance of the individual for the historical formation of law and the legal developments.
\end{abstract}

\section{Keywords:}

law; history; labor; international; organization; Czechoslovakia; Hodač

\section{Klíčová slova:}

právo; historie; práce; mezinárodní; organizace; Československo; Hodač

DOI: $10.14712 / 2464689 X .2020 .32$

Financování: Tento článek vznikl za podpory a v rámci grantového projektu GA ČR reg. č. 17-03398S „Mezinárodní organizace práce a její význam pro rozvoj sociálního práva v Evropě“. 


\section{Dobová zkušenost jako příčina vzniku Mezinárodní organizace práce}

Marcus Tullius Cicero kdysi napsal: Historia vero testis temporum, lux veritatis, vita memoriae, magistra vitae, nuntia vetustatis, qua voce alia nisi oratoris immortalitati commendatur. ${ }^{1}$ Tento citát reflektuje skutečnost, že historie odráží časovou povahu lidské zkušenosti. ${ }^{2}$ Zmíněný jev neplatí pouze pro dějinný průběh života jedince nebo existence společnosti, ale konec konců i pro normativní systémy jako je právo, morálka či náboženství. V právu se pak netýká pouze právních norem nebo principů, nýbrž rovněž jejich recipientů, tj. subjektů práv a povinností a rovněž orgánů, institucí a organizací právo tvořících nebo aplikujících. Právě dobová empirie konvenuje, nejen ohledně svobody, ${ }^{3}$ s poznanou nutností.

A byla to právě dobová zkušenost, která významným způsobem ovlivnila také dějiny pramenů pracovního práva. Konkrétně se od konce první světové války začíná objevovat tendence organizovaného vytváření základů mezinárodního pracovního práva. Objektivní okolnosti, jakými byly tíživá hospodářská situace, která vznikla v důsledku první světové války a následné španělské chřipky nebo revoluce v Rusku a dalších zemích, a s tím související snaha evropských elit vytvořit právní prostředí, jež by otupilo hrany dobového radikalismu řešení sporů mezi zaměstnanci a zaměstnavateli, ${ }^{4}$ vedly ke vzniku na svou dobu pionýrského a pozoruhodného modelu tvorby práva, založeného na sociálním partnerství. Totiž modelu vytváření práva na bázi konsenzu tripartity tří těles - zástupců vlád, zaměstnavatelů a zaměstnanců. ${ }^{5}$ Tento koncept, označovaný také jako princip funkcionální reprezentace, ${ }^{6}$ se ukázal plauzibilním a osvědčil se do té míry, že se posléze začal prosazovat i při právním řešení pracovních otázek na vnitrostátní úrovni. Určité historické analogie ke konceptu tripartity lze možná vidět v kuriovém systému zájmového či stavovského zastoupení v minulosti. Ve starších dějinách ovšem primárním cílem takové organizace nebylo zformování partnerství a dosažení konsenzu, nýbrž mocenská reprezentace.

Budování sociálního partnerství na bázi tripartity se stalo základem fungování Mezinárodní organizace práce, odborné sociální organizace, jejímž posláním bylo vytvořit hospodářskou a sociální spolupráci, ${ }^{7}$ zlepšit pracovní podmínky, sociální situaci, a napomoci zajištění míru ve světě. ${ }^{8}$ Lze bez nadsázky říci, že založení Mezinárodní organizace práce bylo, vzhledem k poměrům, za nichž vznikala, ve své době transkulturní nezbytností pro zachování režimů liberální a sociální demokracie. Projevem čehož bylo i dobové přesvědčení, že Mezinárodní organizace práce představuje „sociální svědomí světa“. 9 Ostatně

CICERO, M. T. De Oratore. Für den Schulgebrauch erklärt von Karl Wilhelm Piderit. Leipzig: B. G. Teubner, 1862, s. 110. [online]. Dostupné na: https://ia802707.us.archive.org/27/items/deoratore00pidegoog/ deoratore00pidegoog.pdf. [cit. 05. 11. 2019].

2 HORSKÝ, J. Čas. In: ŠTORCHOVÁ, L. a kol. Koncepty a dějiny. Proměny pojmů v současné vědě. Praha: Scriptorium, 2014, s. 33.

3 ENGELS, B. Anti-Dühring. Pana Evžena Dühringa převrat vědy. Praha: Svoboda, 1952, s. 98.

4 International Labour Office. Official Bulletin. Vol. I. April 1919-August 1920. Geneva: ILO, 1923, s. 246.

5 BĚLINA, M. a kol. Pracovni právo. 5. vydání. Praha: C. H. Beck, 2012, s. 53.

6 GREGOROVÁ, Z. Právní činnost Mezinárodni organizace práce a jejich vztah k československému právu. Brno: Univerzita J. E. Purkyně, 1988, s. 20-21.

7 TELTŠ́́K, R. Mezinárodní konference práce (Letošní i předešlé). In: Naše doba: revue pro vědu, uměni a život sociální. 1924, roč. XXXII., sešit 10. Praha-Královské Vinohrady: Jan Laichter, s. 585.

8 BĚLINA a kol., c. d., s. 52.

9 TELTŠíK, c. d., s. 590. 
také proto stanul ve fundamentu této organizace jeden z právních dokumentů představujících tehdy gros dobového uspořádání vztahů ve světě - pařŕžského mírového systému. Mezinárodní organizace práce totiž vznikla na základě XIII. kapitoly Versailleské mírové smlouvy a vzhledem k tomu po celé meziválečné období tvořila autonomní složku Společnosti národů. ${ }^{10}$ Právě přináležitost ke Společnosti národů (dnes k OSN) a související snaha o univerzalitu představovaly další dva organizační principy MOP. ${ }^{11}$

Ve jmenované kapitole mírové smlouvy byly vytyčeny následující vůdčí zásady pracovního práva: práce nemá být pokládána za zboží, spolčovací právo zaměstnavatelů a zaměstnanců má být rovné, za práci má být poskytována přiměřená odměna, má být odstraněna dětská práce, má být zajištěna rovnost v odměňování bez ohledu na pohlaví, v pracovním týdnu má být alespoň jeden den volna a denní pracovní doba by měla být osmihodinová, a konečně vytvoření systému dozoru práce. ${ }^{12}$

Vzhledem ke svrchu popsanému významu času z hlediska jurisprudence je vhodné zdůraznit význam Mezinárodní organizace práce nejen z hlediska pracovního práva, ale rovněž jako parciální projev modernizace ve smyslu institucionální transformace ${ }^{13}$ (v př́ipadě MOP se jedná o instituci - organizaci internacionální). Jako každá struktura i Mezinárodní organizace práce měla a má doposud svůj vlastní regulovaný dynamismus, ${ }^{14}$ který reflektuje právě temporální charakter lidské zkušenosti. Ačkoliv se úkoly této mezinárodní organizace v průběhu dějin proměňovaly a stávaly se komplexnějšími, tak, jak se proměňoval a stával komplexnějším svět, v němž Mezinárodní organizace práce funguje, svrchu psané základní poslání zůstalo Mezinárodní organizaci práce zachováno doposud.

\section{Podíl Čechoslováků na počátcích Mezinárodní organizace práce}

Jestliže význam Mezinárodní organizace práce je pro moderní podobu pracovního práva alespoň zčásti doceňován, je třeba říci, že v současnosti bývá spíše opomíjena významná role, kterou při vzniku a fungování této odborné organizace, a tedy i pro stávající podobu pracovního práva v různých zemích světa, sehrála v letech 1918-1938 tehdejší Československá republika. Československo bylo zakládajícím členem Mezinárodní organizace práce. Už u kolébky Mezinárodní organizace práce, totiž při vytváření XIII. kapitoly Versailleské mírové smlouvy, stál vedle zástupců Francie, Spojeného království, Spojených států, Itálie, Japonska, Polska a Kubánské republiky československý delegát, kterým tehdy byl jeden z otců zakladatelů moderního československého státu Edvard Beneš. ${ }^{15}$

Byl to právě budoucí československý prezident, který navrhl, aby byly politické delegace patnáctičlenné komise koncipující uvedenou „pracovněprávní“ pasáž Versailleské smlouvy doprovázeny odbornými poradci, ${ }^{16}$ což vytvořilo příznivé podmínky pro věcný př́stup k tvorbě zmíněného právního dokumentu a tím usnadnilo a urychlilo vznik paktu.

10 Národní archiv, fond 464 Pozůstalost dr. Františka Hodače, karton 220, Mezinárodní úřad práce a jeho ředitel, s. 1. Viz též Slavie, 16. května 1920, s. 3.

11 GREGOROVÁ, c. d., s. 20-21.

12 TOMEŠ, I. Z historie International Labour Organisation (ILO) - Mezinárodní organizace práce (MOP). Fórum sociální politiky, 2017, roč. 10, č. 3, s. 20.

13 K modernizaci ve smyslu institucionální transformace viz HORSKÝ, J. Struktura. In: ŠTORCHOVÁ, L. a kol. Koncepty a dějiny. Proměny pojmů v současné vědě. Praha: Scriptorium, 2014, s. 66.

14 HORSKÝ, Struktura, s. 66.

15 TOMEŠs, c. d., s. 20.

16 Tamtéž. 
Stejně tak to byla právě delegace ČSR, jež ,,předložila memorandum požadující vypracování mezinárodní úmluvy o osmihodinové pracovní době“. ${ }^{17}$ Argumentovala přitom v memorandu, že „,není otázka způsobilejší uklidnit veřejné mínění a mysl pracujících, nežli osmihodinová pracovní doba“". ${ }^{18}$ Tento požadavek byl do Versailleské smlouvy vtělen a stal se jedním z počátečních pilířu aktivit Mezinárodní organizace práce a jejím prostřednictvím i významnou složkou mezinárodního pracovního práva.

Na okraj se sluší dodat, že se Edvard Beneš zasloužil o rozvoj Mezinárodní organizace práce i svými dalšími kroky. Byl to on, kdo přišel s myšlenkou, aby vedení organizace neovládly jen koloniální velmoci, ale aby se na něm významněji podílely i menší státy. Konkrétně Beneš předestřel myšlenku, aby se 2. sekretářem komise mezinárodního pracovního zákonodárství stal zástupce některého malého státu. ${ }^{19}$ Právě tato, také z ,československých kořenư“ vyvěrající schopnost Mezinárodní organizace práce, umožňující zahrnout do fungování svých orgánů nejen ,velké hráče“, nýbrž učinit angažovanými participanty svých aktivit rovněž další státy, se ukázala jako velmi důležitá pro adaptaci organizace na metamorfózy objektivních i subjektivních skutečností. Posléze se ona schopnost přizpůsobení projevila i např. v době studené války, dekolonializace a taktéž vytvářením regionálních konferencí řešících specificky lokální problémy.

Tato dovednost umožnila Mezinárodní organizaci práce flexibilně reagovat na výzvy a potřeby doby. Tedy opět na onu na počátku tohoto článku zmíněnou historickou zkušenost. Právě taková vlastnost bývá nezbytná pro kontinuální přetrvání velkých říší i mezinárodních organizací. Byl to konečně znovu Edvard Beneš, ještě jako ministr zahraničních věcí Československa, který byl na návrh zástupce Velké Británie ${ }^{20}$ na 7 . zasedání Mezinárodní konference práce v roce 1925 zvolen předsedou této konference. ${ }^{21}$ Jednalo se nejen o výraz výběru reprezentanta zastávajícího významnou ústavní funkci, nýbrž i o vyjádření ocenění př́nosu tohoto československého národně socialistického politika pro Mezinárodní organizaci práce a zprostředkovaně tedy rovněž pro pracovní právo.

Edvard Beneš ovšem nebyl jediným československým politikem, který se zasloužil o rozvoj mezinárodní úrovně tvorby pracovního práva svým působením v rámci orgánů Mezinárodní organizace práce $\mathrm{v}$ době mezi dvěma světovými válkami. Působení delegátů z ČSR v MOP bylo dlouhodobé22 a aktivní, což je hodno ocenění též s přihlédnutím ke skutečnosti, že na rozdíl od představitelů anglofonních a frankofonních zemí byly jednací jazyky v Mezinárodní organizaci práce pro československé reprezentanty jazyky cizími.

Na první konferenci posléze Edvarda Beneše nahradil Rudolf Brož, budoucí národní socialista, který se jako člen hospodářské delegace zúčastnil pařížské mírové konference ${ }^{23}$

17 Tamtéž. Text memoranda viz International Labour Office. Official Bulletin. Vol. I. April 1919-August 1920. Geneva: ILO, 1923, s. 245-255.

18 International Labour Office. Official Bulletin. Vol. I. April 1919-August 1920. Geneva: ILO, 1923, s. 246.

19 Tamtéž, s. 5. Tímto státem se tehdy stala Belgie.

20 SKOCH, J. Mezinárodni organizace práce a ČSR. Genese mezinárodní organizace práce, její působení a účast Československa na jejím díle. Praha: Lidová knihtiskárna A. Němec a spol., 1928, s. 103.

21 TELTŠÍK, c. d., s. 590-591.

22 GREGOROVÁ, c. d., s. 88.

23 TOMEŠ, J. BROŽ, Rudolf. In: VOŠAHLÍKOVÁ, P. a kol. Biografický slovník českých zemí. 7. sešit (Bra-Brum). Praha: Libri, 2012, s. 209-210. 
a vystupoval aktivně v komisi pro mezinárodní pracovní zákonodárství. ${ }^{24}$ Brož dokonce navrhl komisi širší pojetí úmluvy o osmihodinové pracovní době, totiž rozšíření působnosti konvence na všechny provozy se zaměstnanci, nejen na provozy průmyslové. ${ }^{25}$ Později byly provozy omezeny na průmyslové a zemědělské ${ }^{26}$ a nakonec ve spojení se zástupci italské vlády byla regulace omezena na zaměstnance v průmyslu a obchodu. ${ }^{27}$

Jmenovat lze dále napřr. národně socialistického senátora Ferdinanda Št’astného, ústředního tajemníka Odborového sdružení československého a sociálně demokratického poslance Rudolfa Tayerleho, či dr. Evžena Šterna. Rudolf Tayerle byl činný rovněž v mezinárodních aktivitách odborů. ${ }^{28}$ Dr. Evžen Štern byl odborovým radou na Ministerstvu práce a sociální péče, později zastával post generálního tajemníka Ústřední sociální pojištovny. ${ }^{29}$ Napsal několik článků týkajících se Mezinárodní organizace práce ${ }^{30}$ a patřil „,k předním expertům na sociální politiku I. republiky“.31 Při svých úvahách sociálních reforem měl Štern mezinárodní rozhled. Inspiraci hledal kupř́kladu také v sovětském plánování, industrializaci a sociálních programech či v Rooseveltově New Dealu. ${ }^{32}$

Pozapomenuta zůstala informace, že se činnosti Mezinárodní organizace práce krátce účastnila rovněž spisovatelka Marie Majerová, ${ }^{33}$ která vzhledem ke svému levicovému smýšlení byla odbornou poradkyní zástupce zaměstnanců na washingtonské konferenci Mezinárodní organizace práce v roce 1919. ${ }^{34}$ Je projevem historického paradoxu, kdy se během relativně krátké doby v důsledku objektivních i subjektivních okolností dokáže zcela změnit postavení jedince a dějiny tuto stopu zachycují a důsledně otiskují. Poradcem delegáta zaměstnanců, tedy „na jedné lodi“ s Marií Majerovou, byl v roce 1919 rovněž Vojtěch Dundr, pozdější tajemník Československé sociálně demokratické strany dělnické, který byl odsouzen v procesu s Miladou Horákovou. V době zmíněného procesu byla naopak Marie Majerová aktivní členkou Komunistické strany Československa a stála tedy takř́ikajíc „,na druhé straně barikády“. ${ }^{35}$

24 International Labour Office. Official Bulletin. Vol. I. April 1919-August 1920. Geneva: ILO, 1923, s. 34, 37-40, 49-50, 56, 71, 131,133, 143.

25 Tamtéž, s. 112.

26 Tamtéž, s. 160.

27 Tamtéž, s. 196.

28 Viz k tomu např. TAYERLE, R. Mezinárodní odborová konference v Bernu. In: Odborové sdružení českoslovanské. Ústřední korespondenční a statistický časopis československých odborných a vzdělávacích spolků, 1919, roč. XXIII, č. 5, Praha: Josef Malý, s. 41-43.

29 Viz RÁKOSNÍK, J. Odvrácená tvář meziválečné prosperity. Nezaměstnanost v Československu v letech 1918-1938. Praha: Karolinum, 2008, s. 22. Rovněž viz Ústředni sociální pojištovna 1926-1936. Praha: Ústřední sociální pojištovna, 1936, s. 17.

30 Např. ŠTERN, E. Československo a Mezinárodní organizace práce. In: Sociální politika v Československé republice. Praha: Sociální ústav Československé republiky, 1928, s. 89-99, nebo ŠTERN, E. O osmihodinové pracovní době. In: Sociální politika v Československé republice. Praha: Sociální ústav Československé republiky, 1928, s. 13-18.

31 Viz RÁKOSNÍK, c. d., s. 22.

32 Tamtéž.

33 Z nejvýznamnějších děl jmenujme sociální a generační román Siréna, naturalistický román Náměstí republiky, avantgardně utopickou Přehradu nebo knihu pro mládež Robinsonka.

$34 \mathrm{SKOCH}$, c. d., s. 41.

35 K životu a dílu Marie Majerové z poslední doby viz např. MANDOVÁ, L. Od Panenství k Divokému Západu. Doba, život a dílo Marie Majerové. Praha: H+H, 2019. 


\section{František Xaver Hodač jako funkcionář Ústř̌edního svazu československých průmyslníků}

Nejvýznamnější českou stopu v Mezinárodní organizaci práce a ve fungování jejích orgánů v meziválečném období ovšem zanechal politik a novinář František Xaver Hodač. Tento absolvent filozofické a právnické fakulty české Karlo-Ferdinandovy univerzity ${ }^{36}$ patřil původně k Masarykovým realistům, aby se posléze transformoval do představitele názorů blízkých Československé národní demokracii, za niž byl také v letech 1929-1935 poslancem a novinářem. V této pozici prosazoval sbližování i s vyhraněně pravicovými politickými uskupeními (např. Národní ligou) a zastával i některé kontroverzní názory, např. vcelku pochvalně se stavěl vůči totalitní fašistické Itálii (především vůči korporativismu a italskému ř́zenému hospodářství). ${ }^{37}$

Díky svým společenským vazbám se F. X. Hodač stal členem předsednictva Svazu českých průmyslníků již v okamžiku schválení stanov této organizace pražským místodržitelstvím dne 8. května 1918, a po vzniku Československa se stal generálním tajemníkem a posléze místopředsedou Ústředního svazu československých průmyslníků. ${ }^{38}$ Svůj význam při získání tohoto postavení F. X. Hodačem jistě měla i skutečnost, že F. X. Hodač náležel mezi představitele českých bank a pojišt'oven, ${ }^{39}$ které hrály již před vznikem Československa $\mathrm{v}$ českém hospodářství nezanedbatelnou roli. Jejich postavení ještě posílilo v meziválečném období.

V Československu totiž proběhl proces tzv. nostrifikace, tj. přesun zahraničních sídel a hospodářského vedení obchodních společností podnikajících na území Československa,

36 František Xaver Hodač byl imatrikulován v roce 1902 na filozofické fakultě a v roce 1903 na právnické fakultě. Viz Filozofická fakulta Univerzity Karlovy, ZS 1902/1903, Archiv Univerzity Karlovy, Matriky Univerzity Karlovy, inv. č. 27, Matrika imatrikulovaných české Karlo-Ferdinandovy univerzity / Univerzity Karlovy H a Právnická fakulta Univerzity Karlovy, ZS 1903/1904, Archiv Univerzity Karlovy, Matriky Univerzity Karlovy, inv. č. 27, Matrika imatrikulovaných české Karlo-Ferdinandovy univerzity / Univerzity Karlovy H. [online]. Dostupné na: http://is.cuni.cz/webapps/archiv/public/person /se/1671311363975513/?____ MG__search_name=HODAČ+FRANTIŠEK\&____ MG_search

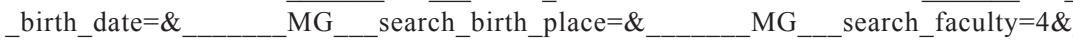
$\overline{\mathrm{MG}} \_$search_year_from $=\& \_$___ $\quad \overline{\mathrm{MG}}$ search_year_to=\&lang $=\overline{\mathrm{cs} \& P S}$ ParcPublicPersonSearchList $=10 \overline{\& S}$ OarcPublicPersonSearchList $=0$ order_prijmeni $/ 0$ order_jmeno\&_sessionId $=1156332 \&$ binding $=1 \& \_\quad B G \_O K=V y h l e d a t \&$ __earch_name $=$ HODAČ + FRANTIŠEK\&search_birth_place $=\&$ search faculty=4 [cit. 24. 08. 2019]. Studoval do 13. 7. 1907. Viz tamtéž. Státovědeckou státnici jako poslední z povinných státnic skládal F. X. Hodač dne 28. května 1907, a to na české Karlo-Ferdinandově univerzitě, tj. v češtině. Povinný jeden státnicový předmět v němčině úspěšně absolvoval ze správního práva. Viz Archiv Univerzity Karlovy, fond Právnická fakulta Německé univerzity v Praze, Knihy zkušebních protokolů státních zkušebních komisí, inv. č. 77, s. 9118. [online]. Dostupné na: http://is.cuni.cz /webapps/archiv/public/book/bo/1625570324201686/197/?lang=cs. [cit. 24. 08. 2019]. Promován byl dne 13. července 1907 za promotorství civilního procesualisty prof. Emila Otta. Viz Archiv Univerzity Karlovy, Matriky Univerzity Karlovy, inv. č. 2, Matrika doktorů (1900-1908), s. 929. [online]. Dostupné na: http:// is.cuni.cz/webapps/archiv/public/book/bo/1662070835117222/344/?lang=cs. [cit. 24. 08. 2019].

37 Viz heslo František Hodač. [online]. Dostupné na https://cs.wikipedia.org/wiki/František_Hodač. [cit. 14. 09. 2019].

38 DURMANOVÁ, M. a kol. Ústřední svaz československého průmyslu 1918-1950. Inventář. Praha: Státní ústřední archiv, 1964, s. 2. K ustavení svazu viz též Národní archiv, fond 372 Ústřední svaz československého průmyslu, inv. č. 83, sign. 0/50/1, karton 24, ustavení ÚSČP. Viz též Národní archiv, fond 464 Pozůstalost dr. Františka Hodače, karton 220, Mezinárodní úřad práce a jeho ředitel.

39 PRŮCHA, V. a kol. Hospodářské a sociální dějiny Československa 1918-1992. 1. dil Obdobi 1918-1945. Brno: Doplněk, 2004, s. 191. 
který probíhal v letech 1919-1929. Hlavní vlna nostrifikace v českých zemích se pak odehrála v letech 1921-1924. Tento proces se opíral zejména o vládní nařízení č. 522/1919 Sb. z. a n. a o zákon č. 12/1920 Sb. z. a n., o podnicích, které mají sídlo mimo území československého státu. Jedním z důsledků nostrifikační právní úpravy a její realizace v praxi byla skutečnost, že řadu obchodních společností či obchodních podílů v nich odkoupily československé banky za výhodné ceny a v ČSR tak došlo k významnému propojení průmyslu a bankovnictví. To napomohlo monopolizaci, koncentraci výroby a kapitálu v průmyslu, zejm. zbrojním, automobilovém, leteckém, elektrotechnickém, obuvnickém, chemickém, a v hornictví a hutnictví. ${ }^{40}$ Díky tomu stát také banky opakovaně v době hospodářských stagnací a krizí sanoval, nebot' se tím snažil předcházet hrozícím dopadům na průmyslová odvětví a zaměstnanost. Ne vždy ovšem tyto snahy skončily úspěšně. Nezřídka pomohly poskytnuté státní peníze jen bankéřum, nikoliv zaměstnancům, což vyvolávalo kritiku tisku (v komunistických novinách se objevoval dokonce pojem „bankokracie“) i levicových politických stran. ${ }^{41}$

$\mathrm{Na}$ druhou stranu díky tomu existovala v Československé republice v letech 19181938 poměrně výrazná organizovanost zaměstnavatelů a zaměstnanců v průmyslu. Svrchu psané skutečnosti rovněž vedly mnoho velkých zaměstnavatelů k uvědomění si výhodnosti vytváření sociálního partnerství, uzavírání kolektivních smluv mezi zaměstnavateli a zaměstnanci ohledně mezd, pracovních, bezpečnostních a sociálních otázek. ${ }^{42}$ Jako perspektivní se totiž v průběhu doby ukázala „taková sociální politika, která... přihlížela k požadavkům zaměstnanců“. ${ }^{43}$ Politika sociálního dialogu formovala specifickou podobu podnikatelské etiky a kultury ${ }^{44}$ zasahující do oblasti pracovního práva. ${ }^{45}$ Samozřejmě tento dialog probíhal v mezích daných historickou dobou, ${ }^{46}$ představami a rámcem dosavadních poměrů, limity právní úpravy i podnikání jako soustavné činnosti za účelem dosažení zisku a také poměrně vysokou organizovaností a sociálním sebeuvědoměním zaměstnanců.

Byl to právě Ústřední svaz československých průmyslníků jako zájmová organizace velkých zaměstnavatelů, zejména ve výše uvedených odvětvích průmyslu, který se snažil sjednocovat postoje zaměstnavatelů, zaujímal k jejich užitku stanoviska a vyjadřoval se k návrhům obecně závazných normativních předpisů, př́p. takové akty inicioval a řešil též problematiku např. kolektivních smluv, mzdových otázek a jednotného postupu v mzdových a sociálních otázkách (nemocenské pojištění, zprostředkovatelny práce atp.). ${ }^{47}$ Logicky se proto stal Ústřední svaz československých průmyslníků organi-

$40 \quad$ PRŮCHA a kol., c. d., s. 133-134, 136.

41 Viz např. článek Vláda uznává úplnou bezradnost v řešení hospodářské krize. Rudé právo, 1. října 1922, č. 230, roč. III, s. 1, nebo Porážka horníků - první výsledek jednotné fronty sociál patriotů s buržoazií. Rudé právo, 17. ř́ina 1922, č. 243, roč. III, s. 1-2, zde se objevuje pojem bankokracie a výslovně jsou zde zmíněni Engliš, Preis a právě Hodač. Dále též viz Ministra financí tanec mezi vejci. Rudé právo, 17. října 1922, č. 243, roč. III, s. 3-4, nebo Veliká hospodářská krize potrvá dlouho. Státnická zkouška buržoazie. Rudé právo, Večerník, 15. listopadu 1922, č. 259, roč. III, s. 1.

42 PRŮCHA a kol., c. d., s. 138.

43 PRŮCHA a kol., c. d., s. 139.

44 Tamtéž.

45 Projevem této etiky bylo i to, že sociální politiku ve prospěch zaměstnanců chválil např. i pravicově orientovaný Karel Kramář. Viz Proč jsem chtěl a chci Národní sjednocení. Národní listy, 28. dubna 1935, č. 117 , roč. 75 , s. 1 . V digitalizované podobě dostupné na: https://cs.wikisource.org/wiki/Pro\%C4\%8D jsem_cht $\%$ C4\%9B1_a_chci_N\%C3\%A1rodn\%C3\%AD_sjednocen\%C3\%AD. [cit. 24. 08. 2019].

46 Jiný př́stup lze sledovat v etapě konjunktury, jiný v čase vrcholící hospodářské krize.

47 DURMANOVÁ a kol., c. d., s. 3. 
zací, která vyslala své představitele jako reprezentanty československých zaměstnavatelů do Mezinárodního úřadu práce. Stejně tak logické bylo, že při volbě delegáta spočinul pohled svazu právě na osobnosti F. X. Hodače. F. X. Hodač, jak již bylo řečeno, stál v čele sekretariátu svazu. Z orgánů svazu - užšího prezidia, širšího prezidia, výborů podle druhu hospodářství a dále právního, ústředního sekretariátu - to byl právě personální substrát sekretariátu, který byl na odborné a právní diskuze nejlépe připraven. Sekretariát tvořily referáty právní, statistický a všeobecný a zaměření referátů odpovídala kvalifikace jeho zaměstnanců a představitelů. ${ }^{48}$

Svým vzděláním, jazykovou vybaveností i rozhledem naplňoval František Xaver Hodač předpoklady pro kvalitní reprezentaci československých zaměstnavatelů na mezinárodní scéně. F. X. Hodač se navíc opakovaně vyjadřoval ve prospěch určité formy sociálního dialogu. Nap̌r. v poznámkách k Mezinárodní organizaci práce si napsal: „Společnost národů má za cíl založit obecný mír a tento mír může vzniknout jen na podkladu sociální spravedlnosti. Pokud přetrvávají pracovní podmínky obsahující nespravedlnost, bídu a strádání působí ... nespravedlnost a je třeba tyto podmínky zlepšit.“49 Model tripartity chápal F. X. Hodač právě ve smyslu opatření určených k předcházení revolucím. Napsal k tomu: „,... nejedná se o přestavbu sociální, které se někteří obávají, jiní vychvalují ... Na legální půdě se provádějí reformy dlouho žádané. "50 Také tyto názory jej kvalifikovaly $\mathrm{k}$ účasti $\mathrm{v}$ organizaci předurčené formovat mezinárodní standardy pracovněprávních otázek. Je nutno již na tomto místě uvést, že se F. X. Hodač na poli internacionální tripartity osvědčil, svým povinnostem dostál, a očekávání do něj vkládaná naplnil.

\section{Působení Františka Xavera Hodače v Mezinárodní organizaci práce v letech 1919-1924}

František Xaver Hodač byl z pozice generálního tajemníka Ústředního svazu československých průmyslníků vyslán jako delegát zaměstnavatelů již na 1. Všeobecnou Mezinárodní konferenci práce, konanou od 29. ř́ijna do 29. listopadu roku 1919 v „,atmosféře naděje a očekávání“ ${ }^{51}$ Byl tehdy jedním ze 4 československých řádných delegátů na konferenci. Všebecné konference se totiž zúčastnili vždy 2 zástupci vlády, 1 zástupce zaměstnavatelů a 1 zástupce zaměstnanců za každý členský stát organizace. ${ }^{52} \mathrm{~F}$. X. Hodač zde byl členem klíčové návrhové komise, též komise pro nezaměstnanost. ${ }^{53}$ Návrhová komise přijímala a vyřizovala podané návrhy a komise pro nezaměstnanost se zabývala jednou z důležitých otázek tvořících náplň jednání konference, když vysoká nezaměstnanost provázela transformaci válečného hospodářství do civilních poměrů. F. X. Hodač rovněž zasedal v organizační komisi. ${ }^{54}$

František Xaver Hodač při zaujímání stanovisek úzce spolupracoval se svými dvěma poradci - Jindřichem Waldesem, podnikatelem spojeným se známou značkou Koh-

\footnotetext{
48 DURMANOVÁ a kol., $c$. $d$., s. 10.

49 Národní archiv, fond 464 Pozůstalost F. X. Hodače, karton 220, K př́jezdu ředitele MúP Alberta Thomase.

50 Tamtéž.

51 [Online]. Dostupné na: https://www.ilo.org/global/publications/world-of-work-magazine/articles/ilo-in -history/WCMS_155819/lang--en/index.htm. [cit. 15. 06. 2019].

52 TELTŠÍK, $c$. d., s. 586.

$53 \mathrm{SKOCH}$, c. d., s. 42.

54 International Labour Office. Official Bulletin. Vol. I. April 1919-August 1920. Geneva: ILO, 1923, s. 476.
} 
-i-noor a Antonínem Kř́ižem. ${ }^{55}$ Právě na této konferenci byla přijata úmluva o osmihodinové pracovní době, jejíž přijetí podporovala nejen československá vláda, ale rovněž zaměstnavatelé, mj. také F. X. Hodač. Důvodem bylo nejen uklidnění zjitřené poválečné atmosféry prosazením požadavku podle československého memoranda mezi zaměstnanci „milovaného a populárního na prvomájových manifestacích“, 56 ale rovněž skutečnost, že se ukázalo, že efektivita práce v reálu s překročením určité hrance pracovní doby klesá. Kupř́ikladu v memorandu obsažená statistika efektivity práce vytvořená komisí pro válečný průmysl Velké Británie ukázala, že při 66hodinové týdenní pracovní době byla odvedena práce v hodnotě 110 , při 55hodinové týdenní pracovní době 134 a při 46hodinové týdenní pracovní době 158 , tj. zdaleka nejefektivnější. ${ }^{57}$ Konference schválila také řadu dalších úmluv. ${ }^{58}$

Největším úspěchem Československa v MOP jako státu, i Františka Xavera Hodače osobně, se v roce 1919 stalo jeho zvolení členem Správní rady Mezinárodní organizace práce. ${ }^{59}$ Správní rada měla v meziválečném období celkem 24 členů. Z nich 12 tvořili zástupci vlád členských států, 6 delegáti zaměstnavatelů a 6 delegáti zaměstnanců. Členové byli voleni z pléna dané skupiny (vláda, zaměstnanci, zaměstnavatelé) na funkční období trrí let. ${ }^{60}$ Správní rada zasedala každé tři měsíce. ${ }^{61}$ Rada připravovala dopředu na základě návrhů vlád a zástupců zaměstnanců a zaměstnavatelů program Všeobecné konference a osnovy dokumentů k projednání, ${ }^{62}$ at’ úmluv (konvencí) či doporučení. „Mezinárodně právní úprava práce znamená úpravu pracovních podmínek prostřednictvím mezinárodních dohod.“63 „Konvence je závaznou formou usnesení MOP, upravující nejdůležitější otázky pracujících, ochrany a bezpečnosti práce."64

Oproti úmluvám doporučení neukládala povinnosti, na něž ještě nenazrála doba, pouze je doporučovala a připravovala podmínky pro budoucí mezinárodní úpravu, ${ }^{65}$ př́ípadně se prostřednictvím doporučení otevíraly otázky, kde byla naděje, že bude Mezinárodní organizací práce doporučená úprava přijata na vnitrostátní úrovni některých států. ${ }^{66}$ Doporučení naznačovala směr zájmu MOP, důležitou problematiku, která měla být řešena v budoucnu, ale na níž ještě nebylo dosaženo konsenzu. ${ }^{67}$ Správní radě jakožto iniciativnímu a rrídícímu orgánu podléhal Mezinárodní úřad práce jako stálý a výkonný orgán MOP

57 Tamtéž, s. 247.

58 Jednalo se o úmluvy č. 2-6 týkající se nezaměstnanosti, ochrany mateřství - zaměstnankyň v určitém časovém úseku po slehnutí, noční práce žen, minimálního věku v průmyslu a noční práce mladistvých v průmyslu. [online]. Dostupné na: https://www.ilo.org/dyn/normlex/en/f?p=1000:12000:::NO:::. [cit. 02. 03. 2019].

59 International Labour Office. Official Bulletin. Vol. I. April 1919-August 1920. Geneva: ILO, 1923, s. 458.

60 Národní archiv, fond 464 Pozůstalost dr. Františka Hodače, karton 220 Mezinárodní úřad práce a jeho ředitel, s. 2.

61 Tamtéž. V současnosti zasedá Správní rada MOP třikrát do roka a má 56 řádných a 66 zastupujících členů.

62 TELTŠÍK, $c$. d., s. 586.

63 GREGOROVÁ, c. d., s. 49.

64 GREGOROVÁ, $c$. d., s. 51.

65 BĚLINA a kol., $c$. d., s. 54

66 TELTŠÍK, c. d., s. 587.

67 GREGOROVÁ, c. d., s. 53. 
dle čl. 388 ve spojení s čl. 393 Versailleské smlouvy. ${ }^{68}$ Konečně nikoliv zanedbatelnou byla pravomoc Správní rady volit ředitele Mezinárodní organizace práce. ${ }^{69}$

Při výkonu své funkce v rámci prvního funkčního období se František Xaver Hodač zúčastnil celkem čtyř všeobecných konferencí. Na 2. konferenci v roce 1920 byly řešeny otázky nadprodukce k uspokojení poválečné spotřeby a ochrana zaměstnanců i nezaměstnaných, když např̀. vyvstaly problémy se zaměstnáváním Němců v reparační oblasti v Porúríi. ${ }^{70}$ Obsahově dominantně se konference orientovala na problematiku námořníků. ${ }^{71}$ Jednou z pravděpodobných příčin byla snaha zapojit výrazněji do činnosti organizace Velkou Británii, jejíž představitelé (konkrétně delegáti vysílaní vládou a zaměstnavateli) představovali při většině hlasování o návrzích dokumentů Mezinárodní organizace práce ve 20. letech 20. století jakousi opozici, snažící se o co nejslabší mezinárodní regulaci projednávaných pracovněprávních témat.

Reprezentace ČSR se vyjádřila k programu konference tak, že se jí z „,námořnických“ témat týká jen vnitrozemská plavba. ${ }^{72}$ Vzhledem $\mathrm{k}$ tématu jednání se F. X. Hodač ${ }^{73}$ zúčastnil této ženevské konference společně s kontraadmirálem Bořivojem Radoňem. ${ }^{74}$ F. X. Hodač hlasoval pro celý program budoucí konference a pro většinu úmluv ${ }^{75}$ a doporučení, včetně témat: omezení práce dětí jako topičů a nočních hlídačů, lékařské kontroly, minimální věk námořníků, námořnický kodex, pojištění a podpory v nezaměstnanosti námořníků i navigátorů atp. s výjimkou stanovení minimální délky pracovní doby námořníků. ${ }^{76}$

Na konferenci v roce 1920 F. X. Hodač důrazně vystoupil k otázkám, které se netýkaly projednávané věcné, tzn. právní matérie, ale byly sto ovlivnit zastoupení států v orgánech MOP a př́padně se i jinak dotknout zájmů československých elit. Tak se F. X. Hodač postavil proti návrhu zástupce Itálie, který chtěl krom př́íslušnosti ke státům a kategorie reprezentace složek tripartity - zaměstnanců, zaměstnavatelů, vlády - přihlížet při složení delegací a obsazení orgánů MOP i k přináležitosti k národnosti. ${ }^{77}$ Tím by pro

68 SKOCH, c.d., s. 154.

$69 \mathrm{SKOCH}$, c. d., s. 159.

$70 \quad$ Viz deník Slavie, 16. května 1920, s. 2.

71 Viz POKORNÝ, P. - FUCHS, M. - HORECKÝ, J. - SAMEK, V. 100 let Mezinárodní organizace práce. Základ sociálního dialogu. Praha: Českomoravská konfederace odborových svazů v nakladatelství Sondy, s.r.o., 2019, s. 28. Speciální pracovně právní konferenci pro námořníky ostatně presumovala již 3. rezoluce komise pro mezinárodní pracovní legislativu pařížské mírové konference. Viz Constitution and Rules. Permanent Labour Organisation. Geneve: International Labour Office, 1921, s. 18. Viz k této konferenci též TCZERCLAS von TILLY, H. Internationales Arbeitsrecht. Unter besonderer Berücksichtigung der Internationalen Arbeitsorganisation. Berlin - Leipzig: Walter de Gruyter, 1924, s. 89-92.

72 ŠTERN, E. Československo a Mezinárodní organizace práce, s. 92.

73 International Labour Office. Bulletin. 20. October 1920. No. 6-7. Geneva: ILO, 1920, s. 1.

74 International Labour Conference. Second Session 15th June - 10th July, 1920. Geneva: International Labour Office, 1920, s. XXXVI.

75 Na konferenci byly přijaty úmluvy č. 7-9 týkající se minimálního věku námořníků, podpory v nezaměstnanosti a zaměstnávání námořníků. [online]. Dostupné na: https:/www.ilo.org/dyn/normlex/en/f ?p=1000:12000:::NO::.: [cit. 02.03. 2019].

76 International Labour Conference. Second Session 15th June - 10th July, 1920. Geneva: International Labour Office, 1920, s. 140-141, 144, 363, 365, 387, 404, 430, 443, 446, 451, 453, 462, 478.

77 Tamtéž, s. 20-21. 
Československo (na rozdíl právě od Italského království) ${ }^{78}$ mohla vzniknout povinnost vysílat v delegaci povinně zástupce svých národnostních menšin a Mezinárodní organizace práce by se tak mohla stát dalším kolbištěm, na kterém by se realizovaly hlasy příslušníků československých menšin kritických k novému státu. ${ }^{79}$ Přes odmítavý přístup k institucionalizaci menšinového zastoupení to bylo právě Československo, v jehož delegacích se pravidelně zástupci národnostních menšin v nemalém počtu vyskytovali. ${ }^{80}$ Podobně odmítavě se F. X. Hodač postavil proti myšlence Austrálie, která chtěla v rámci složení a fungování MOP přihlížet i k principu proporcionality delegátů podle kontinentu, z něhož pocházejí. ${ }^{81}$ Zde by zase hrozilo oslabení Československa vzhledem k tomu, že se jednalo o evropský stát, když většina členských států byla právě z Evropy.

František Xaver Hodač ${ }^{82}$ zastupoval československé zaměstnavatele a současně Správní radu MOP rovněž na 3. Mezinárodní konferenci práce, jež se konala v roce 1921 v Ženevě. ${ }^{83} \mathrm{~F}$. X. Hodač byl na této konferenci členem návrhové komise. ${ }^{84}$ Zatímco předcházející Mezinárodní konference práce se v roce 1920 zabývala převážně pracovními podmínkami specifického segmentu zaměstnanců, měla se podle původního návrhu programu 3. Mezinárodní konference práce z roku 1921 věnovat zejména problematice zaměstnanců v zemědělství, a to rozsáhlé agendě sahající od jejich pracovní doby, přes ochranu před nezaměstnaností, ochranu žen a dětí pracujících v zemědělství (např. věku dětí pro práci v zemědělství, který měl podle čl. I úmluvy činit 14 let), ${ }^{85}$ právo se organizovat a sdružovat za účelem prosazení svých zájmů, až po ochranu před úrazy a nemocemi. ${ }^{86}$ Zařazení problematiky pracovních poměrů v zemědělství mezi první otázky řešené Mezinárodní organizací práce bylo pochopitelné. Zaměstnanci v zemědělství činili v období 1918-1938 nezanedbatelný segment pracovního trhu. ${ }^{87}$

Proti návrhu na přijetí úmluvy věnující se komplexně juristické regulaci právních institutů dotýkajících se zaměstnanců v zemědělství vystoupili zástupci francouzské vlády za podpory delegátů ze Švýcarska. Navrhli, aby byly všechny body týkající se zaměstnanců v zemědělství z pořadu jednání konference staženy. ${ }^{88}$ Zaměstnanci v zemědělství tím měli

78 Podle paktu Společnosti národů se totiž ochrana národnostních menšin dotýkala nově vzniklých států, nikoliv velmocí. Podrobněji k tomu viz PETRÁŠ, R. Menšiny v meziválečném Československu. Právní postavení národnostnich menšin v prvni Československé republice a jejich mezinárodněprávní ochrana. Praha: Karolinum, 2009.

79 Takovým kolbištěm byla ostatně i Společnost národů samotná. Jen čeští Němci se obrátili na Společnost národů souhrnně s 24 peticemi upozorňujícími na údajnou diskriminaci německé menšiny ze strany státních orgánů Československé republiky. Viz např. PITRONOVÁ, A. Čeští Němci jako svébytný prvek mezinárodních vztahů. Bakalářská práce. Masarykova univerzita. Fakulta sociálních studií, Brno: MU v Brně. 2010, s. 14.

80 Viz prŕḱklady dále.

81 International Labour Conference. Second Session 15th June - 10th July, 1920. Geneva: International Labour Office, 1920, s. 20-21.

82 Viz KOLEKTIV AUTORU゚. Fond č. 464 Pozůstalost dr. Františka Hodače 1883-1943. Inventár. Praha: SÚA, 1961, s. II. - III.

83 Podrobněji viz TCZERCLAS von TILLY, c. d., s. 93-100.

84 SKOCH, c. d., s. 66 a 70. Rovněž viz International Labour Conference. Third Session. Geneva 1921. Vol I. First and Second Parts. Geneva: International Labour Office, 1921, s. LXIII.

85 ŠTERN, Československo a Mezinárodní organizace práce, s. 94, 95.

86 ALCOCK, A. History of the International Labour Organisation. London: Macmillian, 1971, s. 53.

87 Viz níže.

88 SKOCH, $c$. d., s. 65. Též TCZERCLAS von TILLY, $c$. d, s. 93-95. 
být z působnosti MOP vyňati, stejně jako byli v té době vyňati např. pracující domorodci v koloniích. Prosazení takového přístupu by ovšem významně omezilo působnost Mezinárodní organizace práce řešit pracovněprávní a sociální problematiku. Znamenalo by totiž, že by v tehdejší době mimo zájem MOP zůstaly pracovní podmínky přibližně 3/4 všech zaměstnanců. ${ }^{89}$ Návrh francouzské vlády byl sice ve většině bodů přehlasován, přesto se podařilo z programu konference většinovým hlasováním tehdejších delegátů zaměstnavatelů a vlád vyjmout délku pracovní doby v zemědělství a některé další otázky. ${ }^{90}$

Celý spor se nakonec dostal až před Stálý soud mezinárodní spravedlnosti, který rozhodnutí většiny členů MOP potvrdil. ${ }^{91}$ Tím byla vytvořena praxe, kdy uvedený soudní orgán Společnosti národů rozhodoval o sporných otázkách týkajících se záležitostí fungování Mezinárodní organizace práce a jejích orgánů, včetně rozhodování o kompetencích. Výsledkem bylo přijetí úmluvy MOP č. 10 o minimálním věku pro vstup do zaměstnání v zemědělství. V Československu došlo k uzavření ratifikace předáním ratifikačních listin dne 31. srpna 1923. Dále byla na této konferenci přijata úmluva č. 11 o svobodě sdružování v zemědělství, 92 úmluva č. 13 o používání běloby v natěračství z r. 1921,93 a konečně úmluva č. 14 o provedení týdenního klidu v průmyslových závodech. Pro všechny tyto úmluvy a rovněž pro doporučení (např. o rozvoji technického zemědělského vzdělávání nebo o volnu v obchodních zařízeních) F. X. Hodač zvedl ruku. ${ }^{94}$

Je třeba dodat, že i přes pozitivní stanovisko československých reprezentantů vlád, zaměstnanců i zaměstnavatelů vyslovené př́imo na konferenci se nakonec v letech 1918-1938 schválené úmluvy ne vždy podařilo v Československu provést do vnitrostátního práva. Z úmluv odhlasovaných svými zástupci Československo neratifikovalo v meziválečném období např. úmluvu č. 12 o odškodňování pracovních úrazů v zemědělství z r. 1921, ${ }^{95}$ úmluvu č. 15 o minimálním věku ženců, úmluvu č. 16 o lékařské péči o mladistvé námořníky, ${ }^{96}$ nebo úmluvu č. 17 o odškodňování pracovních úrazů z roku 1921, ${ }^{97}$ které byly obě ratifikovány až v roce 1950.

Ještě výrazněji se uvedený trend projevil ve 30. letech 20. století, kdy ČSR z úmluv přijatých Mezinárodní organizací práce neratifikovalo většinu. Jmenovat lze např. úmluvu č. 29 o nucené nebo povinné práci z r. 1930, ${ }^{98}$ ta byla ratifikována až v roce 1957, úmluvu č. 37 o povinném invalidním pojištění zaměstnanců v průmyslových a obchodních podnicích a ve svobodných povoláních, jakož i domácích dělníků a osob zaměstnaných

\footnotetext{
89 Viz ALCOCK, c. d, s. 55.

90 Tamtéž.

91 Tamtéž.

92 KOLEKTIV AUTORŮ. Úmluvy Mezinárodní organizace práce ratifikované Českou republikou. I. Sborník úmluv MOP ratifikovaných Českou republikou podle stavu účinného k 1. lednu 2018. Praha: Českomoravská konfederace odborových svazů, 2017, s. 19-20.

93 Tamtéž, s. 163-165.

94 International Labour Conference. Third Session. Geneva 1921. Vol I. First and Second Parts. Geneva: International Labour Office, 1921, s. 307, 310, 318, 320, 331, 356.

95 KOLEKTIV AUTORŮ. Úmluvy Mezinárodní organizace práce ratifikované Českou republikou. I., s. 261-262.

96 [Online]. Dostupné na: https://www.ilo.org/dyn/normlex/en/f?p=1000:12000:::NO::.. [cit. 02. 03. 2019].

97 KOLEKTIV AUTORŮ. Úmluvy Mezinárodni organizace práce ratifikované Českou republikou. I., s. 263-266.

98 Tamtéž, s. 21-29.
} 
v domácnosti z r. $1933,{ }^{99}$ úmluvu č. 38 o povinném invalidním pojištění zaměstnanců v zemědělských podnicích 1933, ${ }^{100}$ úmluvu č. 39 o povinném pojištění pro př́pad smrti v průmyslových a obchodních podnicích a ve svobodných povoláních, jakož i domácích dělníků a osob zaměstnaných v domácnosti z r. 1933, ${ }^{101}$ nebo úmluvu č. 42 o odškodnění nemocí z povolání (revidovaná) 1934. ${ }^{102}$ Úmluvy č. 37-42 ze 30. let 20. století byly ratifikovány Československem až v roce 1949.103 Ratifikace na konci 40. let 20. století byla umožněna sílícím důrazem na sociální práva $\mathrm{v}$ poválečném období.

Neratifikace úmluvy a nepřijetí juristické úpravy právního institutu ze smlouvy v podobě zákona pak znamenaly, že schválení uvedených úmluv ze strany československých zástupců mělo čistě demonstrativní charakter s ohledem na tehdejší dualismus mezinárodního a vnitrostátního práva, ${ }^{104}$ kdy musely být mezinárodní smlouvy, at' parlamentní či prezidentské105 inkorporovány do vnitrostátního právního řádu ČSR. Uvedená skutečnost je ovšem pochopitelná. Vystupování československých delegátů na mezinárodním fóru totiž mělo nejen právní, nýbrž i reprezentativní funkci, a to směrem do zahraničí, ale i pro vnitrostátní publikum. Sloužilo mj. k prezentaci vyspělosti, internacionální zodpovědnosti a kooperativnosti státu i dalších československých částí tripartity, i když realita mohla být poněkud odlišná. Přesto je nutno přiznat, že Československo v letech 1918-1938 náleželo k těm státům, které ratifikovaly a inkorporovaly z konvencí Mezinárodní organizace práce z členských států MOP největší počet.

František Xaver Hodač v souvislosti se svou pozicí funkcionáře zaměstnavatelů v Mezinárodní organizaci práce sehrál v době svého prvního funkčního období (1919-1922) významnou úlohu nejen při prosazování zájmů své sociální skupiny a formování internacionálních standardů pracovního práva, ale taktéž při posilování postavení Československa v mezinárodním společenství. Když Společnost národů ustavila osmičlennou komisi expertů k určení průmyslového charakteru (tzn. vlastně rozvinutosti) jednotlivých států, tvořili ji 4 členové vyslaní Správní radou MOP a 4 členové jmenovaní generálním tajemníkem Společnosti národů. Členem této komise za zaměstnavatele ze Správní rady Mezinárodní organizace práce se stal právě F. X. Hodač. ${ }^{106}$ Tato komise se sešla celkem šestkrát, a to v dubnu, červenci, ř́ijnu, listopadu 1921 a v dubnu a květnu 1922. Nakonec bylo určeno 7 kritérií průmyslové kapacity (počet průmyslového obyvatelstva, poměr průmyslového obyvatelstva k celkovému počtu obyvatelstva, délka železniční sítě, délka železniční sítě

99 KOLEKTIV AUTORŮ. Úmluvy Mezinárodní organizace práce ratifikované Českou republikou. I., s. $273-280$.

100 Tamtéž, s. 281-288.

101 Tamtéž, s. 289-297.

102 Tamtéž, s. 298-301.

103 Tamtéž, s. 12-13.

104 Tento dualismus ovšem nebyl úplný. Viz TOMÁŠEK, M. Podíl čs. práva a diplomacie na fungování meziválečné Evropy a formování evropských integračních uskupení. In: MALÝ, K. - SOUKUP, L. (eds.). Československé právo a právni věda v meziválečném obdobi (1918-1938) a jejich misto ve středni Evropě. Praha: Karolinum, 2010, s. 366-370.

105 Což byly právě úmluvy Mezinárodní organizace práce podle čl. 405 odst. 5 Versailleské úmluvy a $§ 64$ odst. 1 Ústavní listiny z roku 1920. Podle dobového výkladu totiž tyto úmluvy neukládaly státu ani občanstvu hmotná břemena, a to přesto, že po ratifikaci stát zavazovaly a svým obsahem zasahovaly do hospodářského života. Viz ŠTERN, Československo a Mezinárodní organizace práce, s. 37.

106 International Labour Conference., Record of Proceedings, First Annual Meeting October 29, 1919 November 29, 1919. Washington DC: Government Printing Office, 1920, s. 284. 
na $1 \mathrm{~km}^{2}$, spotřeba elektrické energie, spotřeba elektrické energie na 1 obyvatele, tonáž obchodního lod'stva). Vědecké zpracování bylo svěřeno subkomisi, v níž zasedal opět F. X. Hodač. ${ }^{107}$ I přesto, že postavení ČSR na světových trzích začalo, spolu se zlepšující se hospodářskou situací Německa a odbytovou krizí po uspokojení poválečných potřeb trhů zbožím, 108 oslabovat, podařilo se Československu, též za přispění F. X. Hodače při stanovení hodnotících kritérií a jejich rozpracování, být zařazeno mezi nejvyspělejší země světa.

V období Hodačova druhého funkčního období (1922-1925) se světová hospodářská situace změnila. Aktivity Mezinárodní organizace práce poněkud oslabily na její 4. a 5. konferenci vzhledem ke skutečnosti, že první roky této doby nebyly prŕliš příznivé sociálnímu pokroku s ohledem na krizi z nadprodukce. ${ }^{109}$ Přijata byla doporučení ohledně statistiky vystěhovalectví a přistěhovalectví. ${ }^{110}$ Situace se změnila s návratem konjunktury, kdy v roce 1925 Všeobecná konference Mezinárodní organizace práce schválila úmluvy č. 17-20 týkající se úhrady pracovních úrazů, nemocí z povolání, rovnosti v zacházení při řešení pracovních úrazů a noční práce v pekárnách. ${ }^{111}$ Naproti tomu výsledkem hospodářského útlumu byly mj. diskuze o možném ústupu od zakotvení osmihodinové pracovní doby v právním řádu. Začaly se (znovu) ozývat hlasy některých představitelů vlád a zaměstnavatelských organizací, jež považovaly juristickou regulaci délky práce zaměstnanců za zbytečně ingerující do svobody podnikání a zaměstnanecko-zaměstnavatelských vztahů.

To vše i přesto, že úmluva Mezinárodní organizace práce o osmihodinové pracovní době umožňovala ve svém článku 5 a 6 práci přesčas ve stanovených výjimečných případech a v článcích 3 a 4 dávala možnost překročit délku pracovní doby. Osmihodinová pracovní doba se tak nevztahovala na některá odvětví ekonomiky, jinde ji bylo možné překročit. Obdobně československá zákonná regulace - zákon č. 91/1918 Sb. z. a n. o 8hodinové době pracovní umožnila $\mathrm{v} \S 6$ práci přesčas a v $\S 4$ a 5 ministrem stanovené výjimky. Práce presčas mohla činit až 120 dnů v roce. Ve skutečnosti tedy osmihodinová pracovní doba platila jen pro polovinu pracovního roku. Ve druhé polovině roku mohla být (a nezřídka byla, viz níže) desetihodinová denní pracovní doba. K tomu osmihodinová pracovní doba vázala jen zaměstnance $\mathrm{v}$ živnostenských a hornických provozech, u zemědělců se použil zákon jen u pravidelných zaměstnanců, žijících mimo domácnost sedláka a dostávajících pravidelnou denní, týdenní nebo měsíční mzdu. ${ }^{112} \mathrm{Na}$ značnou část zaměstnanců a na úruredníky se osmihodinová doba výkonu zaměstnání, resp. služby nevztahovala. ${ }^{113}$

107 SKOCH, c. d., s. 156.

108 ŠTERN, O osmihodinové pracovní době, s. 17.

109 TELTŠÍK, c. d., s. 588.

$110 \quad$ ŠTERN, c. d., s. 98.

111 [Online]. Dostupné na: https://www.ilo.org/dyn/normlex/en/f?p=1000:12000:::NO::.. [cit. 02. 03. 2019].

$112 \S 1$ zákona č. 91/1918 Sb. z. a n., o 8hodinnové době pracovní.

113 Podle původních výkladů by se teoreticky omezení osmi hodin mohlo vztahovat i na činnost úředníků, pokud byli zaměstnanci v odvětvích, o nichž hovořil zákon. To uváděl napřs. výnos ministerstva pošt a telegrafü č. 54292-I./20 ze dne 5. ř́ijna 1920, který též ríkal, že má být v rámci týdne poskytnuta státním civilním zaměstnancům v týdnu alespoň 32hodinová pracovní přestávka, která má minimálně každý třetí týden připadnout na neděli. Viz FOREJT, J. Sbirka nálezů Nejvyššiho správniho soudu a výnosů ministerstev $v$ služebnich, platových a pensijních záležitostech státních a jiných veřejných zaměstnanců. Svazek I. Praha: Ročenka čs. státních úředníků, 1936, s. 155. Judikatura Nejvyššího správního soudu však potvrdila, že 
Důsledkem relativizace mezinárodněprávní úpravy pracovní doby byl rozsáhlý ústup od osmihodinové pracovní doby ve vnitrostátní úpravě řady zemí, včetně československých sousedů. Nejprve se tak stalo v Německu, kde zákonná úprava nakonec vůbec přijata nebyla. ${ }^{114} \mathrm{~V}$ Polsku byla $\mathrm{v}$ roce 1922 účinnost obecně závazného normativního aktu zavádějícího zásadu 48hodinového pracovního týdne na dva roky, a tím i povinnost ji dodržovat, pozastavena, ${ }^{115}$ a to přesto, že Polsko patřilo mezi státy, jež zavedly osmihodinovou pracovní dobu do právního řádu ještě před přijetím př́íslušné úmluvy č. 1 Mezinárodní organizace práce. Stalo se tak už v roce 1918 dekretem o osmihodinovém pracovním dnu. ${ }^{116}$ Ve Velké Británii zase Státní úřad pro mzdy a pracovní otázky rozhodl, že pracovní doba na železnici činí 10-12 hodin. Spojené království ostatně dotazovalo zachování pracovní doby na půdě Mezinárodní organizace práce ještě v roce 1925, kdy ekonomická konjunktura učinila snahy o odstranění osmihodinové pracovní doby dočasně minulostí. ${ }^{117}$ Pracovní doba vybraných profesí se prodlužovala také kupř́íkladu v USA, Dánsku, Švýcarsku, Španělsku či Holandsku. Lépe na tom nebyly ani totalitní státy. Např. přestože italští fašisté demagogicky převzali požadavek osmihodinové pracovní doby do svého programu od socialistických stran, ${ }^{118}$ uzákonili tuto normu až v roce 1925, ${ }^{119}$ tedy v době vrcholící konjunktury, kdy již ziskům zaměstnavatelů taková úprava nevadila.

V Československu sice byla osmihodinová pracovní doba zachována, ale ze strany zaměstnavatelů docházelo $\mathrm{k}$ opakovaným požadavkům na její prodlužování, případně na zavedení výjimek ze zákazu noční práce. ${ }^{120}$ Souviselo to mj. se skutečností, že v důsledku hospodářské krize z let 1921-1923 došlo k racionalizaci, tzn. rozsáhlému propouštění zaměstnanců (např. v ČSR v kovoprůmyslu šlo až o 70 \% pracovníků), ${ }^{121}$ a zbylí zaměstnanci pak museli pracovat o to intenzivněji. Navíc byla využívána svrchu psaná možnost práce přes čas a stanovení výjimek. Pro př́íklad, v roce 1921 bylo v Československu ministerstvem povoleno jako výjimka odpracovat 360000 pracovních dnů, práce přesčas se

poměr služby (nejen státní, ale i samosprávné) je poměrem veřejnoprávním založeným na loajalitě a službě. Viz např. Rozsudek Nejvyššího správního soudu č. 25 ze dne 13. listopadu 1920 v BOHUSLAV, J. V. Sbirka nálezů Nejvyššiho správního soudu ve věcech administrativních. Svazek II. Nálezy z roku 1920 (čis. 290-648). S dodatky. Praha: Právnické nakladatelství v Praze, 1920, s. 783-792. V důsledku této odlišnosti se pak použila zásada lex specialis derogat legi generali, tzn. že již z povahy právního poměru subjektů nebylo možné použít zásadu rovnosti zaměstnanců.

114 ŠTERN, O osmihodinové pracovní době, s. 17.

115 MENCL, V. Na cestě k jednotě. Praha: NPL, 1964, s. 23-24.

116 Podle čl. 1 dekretu ode dne účinnosti tohoto dekretu. Dekret o osmihodinovém pracovním dnu ze dne 23. listopadu 1918, publikovaný v Dziennik Praw Państwa Polskiego z 1918 r., nr 17, poz. 42. [online]. Dostupné na: https://pl.wikisource.org/wiki/Dekret_o_8-mio_godzinnym_dniu_pracy. [cit. 11. 06. 2019]. Národní archiv, fond 464 Pozůstalost dr. Františka Hodače, karton 220, deník Národní listy ze dne 22. ř́jna 1925.

118 QUATERMAINE, L. Mussolin's Last Republic. Propaganda and Politics in the Italian Social Republic (R.S.I.) 1943-45. Exter: Elm Bank publications, 2000, s. 40.

119 BURGER, M. The Shaping of Western Civilization. From Antiquity to the Present. Toronto (Ontario): University of Toronto Press, 2013, s. 433.

120 Viz Proti útoku na noční klid dělnictva pekařského. Odborové sdružení českoslovanské. Ústředni korespondenční a statistický časopis československých odborných a vzdělávacích spolků, 1923, roč. XXVII, č. 1, s. 12.

121 DUNDR, V. Těžké následky hospodářské krize v kovoprůmyslu. Odborové sdruženi českoslovanské. Ústředni korespondenčni a statistický časopis československých odborných a vzdèlávacích spolků, 1923, roč. XXVII, č. 1, s. 5. 
pak pravidelně týkala cca 20 \% zaměstnanců, na které se osmihodinová pracovní doba vztahovala, což bylo podle některých statistik až 1500000 zaměstnanců. ${ }^{122}$ Zachování osmihodinové pracovní doby se proto na počátku 20. let 20. století stalo znovu heslem na 1. máje. ${ }^{123}$ Nutno říci, že F. X. Hodač, na rozdíl od jiných zástupců zaměstnavatelských svazů, veřejně na konferencích Mezinárodní organizace práce proti osmihodinové pracovní době nevystoupil, byt' sám ve svých poznámkách uvažoval nad její neúčelností pro určitá odvětví, konkrétně pro zemědělství, vzhledem k nutnosti sezónních prací atp. ${ }^{124}$

$\mathrm{Na}$ 4. Mezinárodní konferenci práce v Ženevě v roce 1922 byl F. X. Hodač delegátem zaměstnavatelů jako místopředseda Svazu československých průmyslníků ${ }^{125}$ a členem Správní rady (plnil tehdy již své druhé funkční období pro roky 1922-1925). ${ }^{126}$ Tentokrát jej doprovázel a spolupracoval s ním jako poradce za zaměstnavatele Jan Lobkovic. ${ }^{127}$ Nadto, vzhledem k Hodačově dlouhodobé účasti v orgánech MOP a nabytým zkušenostem, byl toho roku F. X. Hodač zvolen za jednoho ze šesti zaměstnavatelských členů celkem 24členné návrhové komise, která vedle řídící komise hrála zásadní roli z hlediska přípravy a průběhu věcné stránky jednání konference Mezinárodní organizace práce. ${ }^{128} \mathrm{~F}$. X. Hodač však toho roku získal také důležitou pozici z hlediska personálií MOP, čímž rovněž mohl ovlivnit výsledky jednání Všeobecné konference. F. X. Hodač se totiž stal členem ověřovací komise, orgánu kontrolujícího, zda delegáti opravdu reprezentují vlády a ostatní složky tripartity (v roce 1922 se diskutovalo o Portugalsku, Chile a Rakousku). F. X. Hodač zastupoval Československo a jeho zaměstnavatele též v komisi pro organizačně-institucionální reformu. ${ }^{129}$ Také byl členem komise statistiky migrace. ${ }^{130}$ Připravoval a hlasoval pro doporučení týkající se komunikace MOP ve věci statistiky a dalších informací týkajících se migrace, emigrace, repatriace emigrantů. ${ }^{131}$

Rovněž na 5. Mezinárodní konferenci práce, která proběhla v Ženevě ve dnech 22.-29. ř́ijna 1923 F. X. Hodač jako místopředseda Svazu průmyslníků a člen Správní rady významně participoval, a to jako člen návrhové komise a místopředseda komise připravující návrh dokumentů k inspekci práce. ${ }^{132}$ Podílel se, společně se svým zástupcem Josefem

122 ŠTERN, O osmihodinové pracovní době, s. 16.

123 Viz Odborově organizovanému dělnictvu a úřednictvu. Odborové sdružení českoslovanské. Ústřední korespondenční a statistický časopis československých odborných a vzdélávacích spolků, 1923, roč. XXVII, č. 8, s. 89 .

124 Národní archiv, fond 464 Pozůstalost dr. Františka Hodače, karton 220, F. Hodač o průmyslu v Československu 8. července 1921.

125 International Labour Conference. Fourth Session. Geneva 1922. Vol I. First and Second Parts. Geneva: International Labour Office, 1922, s. XLVIII.

126 Tamtéž, s. 268 a 594.

127 Tamtéž, s. XLVIII. Pravděpodobně šlo o právníka Jana Lobkowicze (1885-1952), který v té době spravoval rozsáhlý rodový majetek tehdy nezletilého Otokara Lobkovice. [online]. Dostupné na: https://www .lobkowicz-melnik.cz/historie-rodu-lobkowicz/. [cit. 15. 04. 2019], a vlastnil statek a zámek v Drahenicích. Viz Lobkowicz Jan. [online]. Dostupné na: https://www.historickaslechta.cz/osobnosti/lobkowicz -jan-1885-\%E2\%80\%A0-1952-signatar-tri-sl-deklaraci-2/. [cit. 15. 04. 2019].

128 Národní listy, 16. listopadu 1923, s. 5.

129 International Labour Conference. Fourth Session. Geneva 1922. Vol I. First and Second Parts. Geneva: International Labour Office, 1922, s. LIII.

130 Tamtéž, s. 32.

131 Tamtéž, s. 387.

132 International Labour Conference. Fifth Session. 22.-23. October Geneva 1923. Geneva: International Labour Office, 1923, s. XLIII, XLVII a LI. 
Vaňkem, ${ }^{133}$ na návrzích úmluv a doporučení týkajících se inspekce práce, a to jednak předmětu inspekce práce - kontroly dodržování zákonů ochrany zaměstnanců a také pravomocí a povinností inspektorů práce. Mj. mezi práva inspektora podle závěrů konference náleželo právo nařídit bezprostřední opatření a navrhnout odstranění závad s přiměřenou lhůtou. ${ }^{134}$ F. X. Hodač byl jedním z těch zástupců, již prosadili, že možnost strany odvolat se proti závěrům inspektora $\mathrm{k}$ vyšší instanci měla odkladný účinek.

Oproti tomu Velká Británie prosadila výhradu, že postavení inspektorů práce může být oslabeno vnitrostátní legislativou, protože ve Spojeném království inspektoři práce nemohli činit rozhodnutí, ale pouze zjišt'ovali stav a rozhodnutí přijímali jejich nadř́zení. ${ }^{135}$ F. X. Hodač se z pozice místopředsedy osobně podílel rovněž na činnosti komise k prŕpravě návrhů regulace inspekce práce, jak je uvedeno výše. Tato komise připravovala návrh dokumenti̊ právní úpravy kvalifikačních předpokladů pro inspektory a prosadila požadavek technického vzdělání inspektorů a rovněž možnost zaměstnanců hlásit inspektorům nedostatky v pracovněprávních otázkách. ${ }^{136} \mathrm{~V}$ roce 1923 byla rovněž poprvé předložena na konferenci Mezinárodní organizace práce otázka nakládání s cizími zaměstnanci jako s vlastními při odškodňování úrazů v práci - cílem bylo vytvoření mezinárodních standardů právní úpravy. A to v podobě, jež umožňovala, aby prŕíslušníkům jiných členských států a členům jejich rodin při pracovních úrazech bylo poskytnuto stejné zacházení jako vlastním občanům na základě principu zákazu diskriminace. ${ }^{137}$ F. X. Hodač hlasoval pro rovné nakládání se zaměstnanci cizími při odškodňování úrazů - „hlasů proti nebylo“.138 Přesto se úmluvu MOP č. 19 ohledně rovného zacházení při odškodňování pracovních úrazů podařilo nakonec schválit až v roce 1925.

Důležitým tématem, řešeným poprvé na Všeobecné konferenci MOP v roce 1923, byla otázka účasti zástupců fašistické Itálie v orgánech Mezinárodní organizace práce. Jednalo se totiž o první konferenci konající se po fašistickém získání moci po tzv. Pochodu na Rím. ${ }^{139}$ Problém přitom nepředstavovala ani tak účast zástupců fašistické vlády z hlediska ideologického. Tenze vyvolávala primárně otázka, nakolik lze na fašistický korporativismus uplatnit zásadu autonomie, resp. vzájemné nezávislosti jednotlivých tripartitních skupin, ${ }^{140}$ tzn. podřadit jej do tripartitního systému institucí MOP, vzhledem k neexistenci na vládě nezávislých zaměstnaneckých organizací. Italští zaměstnanci spolu se zaměst-

133 Tamtéž, s. XLIII. Josef Vaněk (1895-1960) byl pracovníkem Svazu československých průmyslníků. Viz Příjmení Vaněk. [online]. Dostupné na https://www.prijmeni.cz/Van\%C4\%9Bk\&tab=4\&page=5. [cit. 05. 07. 2019]. Oproti jiným spolupracovníkům F. X. Hodače působil Vaněk v Mezinárodní organizaci práce dlouhodoběji a dokonce zastupoval F. X. Hodače na zasedáních Správní rady, když se ten nemohl zasedání z mimořádných důvodů zúčastnit. Viz Národní archiv, fond 464 Pozůstalost dr. Františka Hodače, karton 220. Národní listy, 22. října 1925. Rovněž publikoval ohledně otázek národního hospodářství. Viz např. VANĚK, J. Bída a blahobyt národů. Základy hospodářského myšlení XX. věku. Praha: Orbis, 1935.

134 Národní listy, 16. listopadu 1923, s. 5.

135 Tamtéž.

136 Tamtéž.

137 Takovou koncepci lze přirovnat k doložce národního zacházení požadované u zboží a služeb Světovou obchodní organizací např. v čl. III. GATT anebo k principu rovného zacházení zmíněného v bodě 22 usnesení Nejvyššího soudu správního 6 Ads 88/2006-132 ze dne 21. 06. 2009.

138 SKOCH, c. d., s. 105.

139 Události 27.-29. ř́ijna 1922, v souvislosti s nimiž italský král Viktor Emanuel III. jmenoval Mussoliniho předsedou vlády Italského království.

140 Pojem zásady autonomie skupin převzat z GREGOROVÁ, c. d., s. 23. 
navateli z rozhodnutí státu vytvářeli ve fašistickém režimu syndikáty a ústřední spojené korporace zaměstnanců a zaměstnavatelů měly povahu státních orgánů. ${ }^{141}$ Přestože k zákonné úpravě v tomto směru došlo především až po tzv. italské deflační krizi v letech 1926/1927, a to zákonem o právní úpravě kolektivních vztahů pracovních ze dne 3. dubna 1926, a Chartou práce ze dne 21. dubna 1927, ${ }^{142}$ vnímali dělníci a jejich zástupci zúčastnění v MOP tento trend již od počátku. Fašisté také vzali zaměstnancům právo stávkovat. ${ }^{143}$ Jak již bylo řečeno výše, F. X. Hodač měl z důvodů politicko-ekonomických poměrně benevolentní stanovisko k italskému fašismu. Současně zastupoval zájmy zaměstnavatelů, které byly obvykle bližší pozicím zástupců vlád než představám zástupců zaměstnanců.

Proto se nelze divit, že svým hlasováním patřil k těm zástupcům vlád a zaměstnavatelů v Mezinárodní organizaci práce, kteří umožnili většinovým hlasováním, překonávajícím odpor zástupců zaměstnanců, přijetí představitelů korporací jako zástupců japonských a italských zaměstnanců. ${ }^{144}$ Antifašistické stanovisko vyjádřil v diskuzi nejvýrazněji zástupce francouzských zaměstnanců. ${ }^{145}$ Otázka připuštění italských „zaměstnaneckých“ zástupců na Všeobecnou konferenci MOP se pak objevovala na pořadu dne konferenčních schůzí po zbytek dvacátých let 20. století. F. X. Hodač pokaždé setrval na svém původním názoru a reprezentaci fašistického delegáta mezi zaměstnanci, společně s ostatními představiteli vlád a zaměstnavatelů, podpořil. ${ }^{146}$

Je ovšem třeba zmínit, že protichůdná stanoviska ke korporativismu či jiným aliberálním hospodářským systémům nebyla dána pouze přístupy konceptuálními a právními, ale rovněž politickými. Lze totiž připomenout obdobný spor ohledně zachování čistoty tripartitního modelu, v němž si jeho protagonisté jen vyměnili strany. Už v roce 1934 poté, co SSSR vstoupil do Společnosti národů, bránili zástupci zaměstnavatelů a některých vlád přijetí sovětských zástupců do MOP s argumentem, že v Sovětském svazu neexistují svobodní, na státu nezávislí, zaměstnavatelé. ${ }^{147}$ Když se pak v roce 1954 Svaz sovětských socialistických republik do Mezinárodní organizace práce vrátil, byli to právě zástupci vlád a zaměstnavatelů nekomunistických zemí, kteří odmítali členství zástupců zaměstnavatelů ze států s tzv. plně socializovanými ekonomikami (tj. zemí východního bloku),

141 Viz DRAŽÍLEK, K. Italské hospodářství a hospodářská politika v 10 letech fašismu. In: Zahraniční politika. Sbornik pro studium otázek mezinárodních, politických, hospodářských a právních s přilohou Věstník Ministerstva zahraničních věcí. 1933. roč. XII. Praha: Orbis, 1933, s. 249. Tato koncepce byla výslovně zakotvena v čl. 3 zákona o právní úpravě kolektivních vztahů pracovních ze dne 3. dubna 1926. Viz tamtéž. Viz DRAŽÍLEK, c. d., s. 98 a 247.

143 Viz DRAŽÍLEK, c. d., s. 248.

144 International Labour Conference. Fifth Session. 22.-23. October Geneva 1923. Geneva: International Labour Office, 1923, s. 88 a 191.

145 Tamtéž, s. 181-187.

146 Jednotlivá hlasování v letech 1924-1930 viz International Labour Conference. Sixth Session. Geneva 1924. Geneva: International Labour Office, 1924, s. 270, International Labour Conference. Seventh Session. Geneva 1925. Geneva: International Labour Office, 1925, s. 77, International Labour Conference. Eight Session. Geneva 1926. Vol. I. Geneva: International Labour Office, 1926, s. 184, International Labour Conference. Tenth Session. Geneva 1927. Geneva: International Labour Office, 1927, s. 92, International Labour Conference. Eleventh Session. Geneva 1928. Vol. I. Geneva: International Labour Office, 1928, s. 162, International Labour Conference. Fourteenth Session. Geneva 1930. Vol. I. Geneva: International Labour Office, 1930, s. 240.

GREGOROVÁ, c. d., s. 23. 
když namítali, že se v takovém případě nejedná o zástupce zaměstnavatelů, nýbrž opět o delegáty vlád. ${ }^{148}$

Na 6. zasedání Všeobecné konference MOP, konané v červnu až červenci roku 1924, Československo vystoupilo svou reprezentací i aktivitou jako velmoc. Se svými 19 členy ( 2 delegáti vládní s 2 poradci, 1 delegát zaměstnavatelů s 6 poradci, 1 delegát zaměstnanců s 6 poradci a 1 sekretář) mělo Československo druhou nejpočetnější delegaci hned po Velké Británii (28 členů). Dokonce byla rozsáhlejší než delegace Francie (18členná delegace) nebo Německa (17 zástupců). Celkem se této konference zúčastnilo 124 delegátů, 100 technických poradců a další osoby ze 39 států světa. ${ }^{149}$

Oproti jiným delegacím nereprezentovali Československo jen zástupci nacionální majority. Menšiny sice nebyly zastoupeny rovnoměrně, ale o to bylo jejich delegátů více. Z celkového počtu 19 československých delegátů bylo 8 osob německého původu, tj. téměř polovina. ${ }^{150}$ Zastoupeni byli vedle zástupců z pohraničí též zaměstnavatelé ze Slovenska. ${ }^{151}$ Dobový tisk, možná poněkud populisticky a nepřesně, spojoval kvantitu zastoupení s podílem na rozhodování organizace a budujíce obraz Československé republiky jako sociálního státu referovaly noviny ${ }^{152}$ o pozici Československa v čele světové sociální politiky s odkazem na proroctví Slepého mládence, starobylou českou pověst, kdy měl dotyčný mládenec věštit budoucí velikost českého národa. ${ }^{153}$

I zde byl František Xaver Hodač členem návrhové komise, ${ }^{154}$ dále pak komise pro využití volného času pracujících, ${ }^{155}$ členem komise pro týdenní zastavení práce ve sklářských provozech, ${ }^{156}$ komise pro noční práci v pekárnách, ${ }^{157}$ komise pro nezaměstnanost. ${ }^{158}$ Nejvýznamnější funkcí na této konferenci, kterou F. X. Hodač poprvé zastával, byl post místopředsedy konference za skupinu zaměstnavatelů. Vyslovené důvěry se zhostil čino-

148 Viz k tomu např. POKORNÝ - FUCHS - HORECKÝ - SAMEK, c. d., s. 32, též HUGHES, S. HAWORTH, N. The International Labour Organisation. Coming in from the Cold. London - New York: Routledge, 2011, s. 14, a JOHNSTON, G. A. The International Labour Organisation. Its work for social and economic progress. London: Europa Publications, 1970, s. 27.

149 Národní archiv, fond 464 Pozůstalost dr. Františka Hodače, karton 220. Lidové noviny, 8. července 1924, s. 1.

150 Tamtéž.

151 Byli to Ervin Hexner, Rodolph Fernegg a Arnold Seidemann. Rodolph nebo též Rudolf Fernegg byl funkcionářem Svazu německého průmyslu v ČSR, měl blízko k Německé národní straně (DNP) a po 2. světové válce patřil k zakladatelům Sudetoněmeckého krajanského sdružení. Viz MAKARIUSOVÁ, M. Fernegg Rudolf. In: Biografický slovnik českých zemí. Sešit 16 (Ep-Fe). Praha: Historický ústav - Academia, 2013, s. 130. Ke vzniku Svazu německého průmyslu a důvodům pozdějšího založení organizace ve vztahu ke vzniku nového státu a nacionálním eventualitám viz např. BOYER, Ch. Nationale Kontrahenten oder Partner? Studien zu den Beziehungen zwischen Tschechen und Deutschen in der Wirtschaft der ČSR (1918-1938). München: Oldenbourg, 1999, s. 37-43.

152 Národní archiv, fond 464 Pozůstalost dr. Františka Hodače, karton 220. Lidové noviny, 8. července 1924, s. 1.

153 Obsah proroctví viz např. JIRÁSEK, A. Staré pověsti české. 3. vyd. Praha: Státní pedagogické nakladatelství, 1959, s. 250-253.

154 International Labour Conference. Sixth Session. Geneva 1924. Geneva: International Labour Office, 1924, s. L.

155 Tamtéž, s. LI.

156 International Labour Conference. Sixth Session. Geneva 1924. Geneva: International Labour Office, 1924, s. LIV.

157 Tamtéž, s. LVIII.

158 Tamtéž, s. LIX. 
rodě, když společně s německým a britským delegátem velmi aktivně vystoupil za zájmy zaměstnavatelů s požadavkem, aby se provoz ve sklářských továrnách neomezoval stanovením délky pracovní doby. ${ }^{159}$ Právě tématem délky pracovní doby ve sklářských provozech se 6. Všeobecná konference MOP zaobírala.

V rámci diskuzí o znění úmluvy o délce pracovní doby ve sklářských provozech se F. X. Hodač vyslovil proti návrhům zaměstnanců, kteří se dívali pohledem progresivistickým a internacionálním, když chtěli vypustit možnost výjimky ze zastavení práce z ekonomických důvodů, což označovali za př́liš kaučukový pojem, jak vyplynulo z vystoupení belgického a francouzského delegáta zaměstnanců. ${ }^{160}$ Postoje F. X. Hodače i aktivismus v uvedeném tématu, který překračoval jeho běžné působení při projednávání návrhů smluv a doporučení, byly bezpochyby formovány existencí významného sklářského průmyslu v Československé republice a zájmem podnikatelů působících v tomto segmentu průmyslu o plynulé fungování provozů a zachování z nich plynoucích zisků. Vzhledem k tomu, že se F. X. Hodačovi nepodařilo dostatečně změnit znění úmluvy, hlasoval nakonec F. X. Hodač proti návrhu této úmluvy. ${ }^{161}$

Tímto hlasováním také symbolicky končí etapa, kdy F. X. Hodač hlasoval obvykle pro všechny či alespoň pro převážnou většinu Správní radou, tj. orgánem, jehož byl sám členem, předložených návrhů úmluv a doporučení Mezinárodní organizace práce. Od roku 1924 až do konce 20. let 20. století, tzn. ve druhé polovině prvního desetiletí existence a fungování MOP, lze z hlediska analýzy statistik hlasování na Všeobecných konferencích zařadit naopak F. X. Hodače mezi ty delegáty Mezinárodní organizace práce, kteří hlasovali nezřídka proti dokumentům schvalovaným její Všeobecnou konferencí. Tak v roce 1924 hlasoval F. X. Hodač např. proti doporučení o trávení volného času, ${ }^{162}$ anebo proti návrhu úmluvy o noční práci v pekárnách, ${ }^{163}$ který byl nakonec schválen až následující rok. Vedle pracovněprávních otázek se F. X. Hodač jako zástupce zaměstnavatelů z MOP rovněž vedle zástupce zaměstnanců z MOP zúčastnil v r. 1924 na výzvu Společnosti národů schůze Koordinační komise pro přípravu odzbrojovací konference. ${ }^{164}$

Odzbrojovací konference vycházela z odkazu části V. Versailleské mírové smlouvy (čl. 159-213), ${ }^{165}$ která omezovala Německo v ozbrojených silách či obranných a útočných mechanismech. Jednalo se o př́ipravu mj. Ženevského protokolu - Mezinárodní úmluvy o zákazu použití plynů a bakteriologických zbraní ve válce -, když tyto odzbrojovací trendy měly kořeny již v roce 1922. ${ }^{166}$ Výraznou měrou se o projednávání Ženevského protokolu zasloužil Edvard Beneš, ${ }^{167}$ když se mu kompromisním vystupováním (nejen) na

\footnotetext{
159 Tamtéž, s. 376-379 a 395.

160 Tamtéž, s. 380-381.

161 Tamtéž, s. 899.

162 Tamtéž, s. 443.

163 Tamtéž, s. 483.

164 International Labour Conference. Seventh Session. Geneva 1925. Geneva: International Labour Office, 1925, s. 930 .

165 Text viz Treaty of peace with Germany (Treaty of Versailles). [online]. Dostupné na: https://www.loc.gov /law/help/us-treaties/bevans/m-ust000002-0043.pdf (v knihovně Kongresu USA). [cit. 13. 08. 2019].

166 Viz PROCHÁZKA, R. Nová tvář problému bezpečnosti. In: Zahraniční politika. Sborník pro studium otázek mezinárodnich, politických, hospodářských a právních s př́lohou Věstník Ministerstva zahraničních věcí. Leden 1935. Roč. XIV. Praha: Orbis, 1935, s. 80.

167 PROCHÁZKA, Nová tvář problému bezpečnosti, s. 81.
} 
V. jubilejním shromáždění Společnosti národů podařilo sblížit britské představy limitované angažovanosti založené pouze na odzbrojení a arbitráži, prezentované tehdy labouristickým premiérem Ramsay McDonaldem, s francouzským požadavkem odzbrojení založeného na bezpečnosti, kdy podle názoru francouzského ministerského předsedy Édouarda Heriotta z Republikánské strany radikálů a radikálních socialistů ,jakákoliv spravedlnost bez síly je bezmocná“. ${ }^{168}$ Francouzi totiž chápali ochranu míru ve smyslu ochrany versailleského mírového systému, tzn. určitého konkrétního, právně sjednaného výstupu, zatímco Angličané pod pojmem ochrany míru rozuměli mezinárodní regulaci zbrojení a obecné deklarace řešení územní integrity. ${ }^{169}$ Výsledkem úsilí Společnosti národů v tomto směru pak mj. byly Locarnské dohody.

Z protokolů mezinárodních konferencí se zdá, že se Mezinárodní organizace práce, jako specializovaná odborná organizace soustřed'ující svou pozornost na pracovněprávní otázky, necítila být kompetentní k aktivnějšímu působení při odzbrojovacích snahách. A to z důvodu, že těžiště její činnosti bylo jinde. I jejím cílem však, s ohledem na znění tehdejších základních dokumentů MOP, bylo zachování míru, byt' se tohoto cíle snažila dosáhnout činností na odlišném poli a jinými metodami než odzbrojovací konference. Také s ohledem na tento svůj cíl a na propojenost se Společností národů a rovněž na princip tripartity vybrala Mezinárodní organizace práce své zástupce do procesu podporujícího odzbrojovací úsilí. F. X. Hodač se tak stal jakoby mimoděk aktérem v další významné oblasti aktivit formující podobu meziválečné Evropy. V této roli právo vyměnil za politiku, která mu ovšem byla stejně blízká. I přes okrajový podíl by ani tato účast F. X. Hodače na úsilí o internacionální demilitarizaci neměla být zapomenuta.

\section{Stručně k dalšímu působení Františka Xavera Hodače v Mezinárodní organizaci práce do konce 20. let 20. století}

V následujících dvou funkčních obdobích, zasahujících do 20. let 20. století (1925-1928 a 1928-1931), pokračovala nadále činnost Františka Xavera Hodače v Mezinárodní organizaci práce, a to jak výkonem funkcí v jejích orgánech, tak také činností při pracovněprávní normotvorbě. F. X. Hodač se zúčastnil všech všeobecných konferencí s výjimkou 13. konference konané v roce 1929, kdy jej zastoupil tajemník Svazu československého průmyslu Josef Vaněk, ${ }^{170}$ který se v průběhu dvacátých let stal F. X. Hodačovi při jeho mezinárodních aktivitách neocenitelným poradcem a pomocníkem. V letech 1925-1930 byl F. X. Hodač opakovaně členem návrhové komise, ${ }^{171}$ řídící komi-

168 Viz DEJMEK, J. Edvard Beneš. Politická biografie českého demokrata. Část první-revolucionár a diplomat (1884-1935). Praha: Karolinum, 2006, s. 381-385.

169 PROCHÁZKA, R. Anglie a kolektivní bezpečnost. In: Zahraniční politika. Sborník pro studium otázek mezinárodnich, politických, hospodářských a právních s př́lohou Věstník Ministerstva zahraničních věcí. Leden 1935. Roč. XIV. Praha: Orbis, 1935, s. 583-854.

170 International Labour Conference. Thirteenth Session. Geneva 1929. Geneva: International Labour Office, 1929, s. XXXIX.

171 International Labour Conference. Seventh Session. Geneva 1925. Geneva: International Labour Office, 1925, s. LXVII, International Labour Conference. Tenth Session. Geneva 1927. Geneva: International Labour Office, 1927, s. 11, International Labour Conference. Twelth Session. Geneva 1929. Vol. I. Geneva: International Labour Office, 1929, s. LVI a International Labour Conference. Fourteenth Session. Geneva 1930. Vol. I. Geneva: International Labour Office, 1930, s. LIV. 
se $^{172}$ a od roku 1926 byl jako jeden z nejdlouhodobějších členů Správní rady i delegátů vybrán za jednoho ze tř́ místopředsedů konference. ${ }^{173}$ Každá konference měla vždy tři místopředsedy. Z nich jeden byl vybírán z řad představitelů zaměstnavatelů, jeden $\mathrm{z}$ řad zaměstnanců a jeden z řad zástupců vlád. Předsedy a místopředsedy se stávali obvykle významné osobnosti, které se dlouhodobě podílely na fungování Mezinárodní organizace práce nebo byly na konferenci přítomny. Např́íklad, jak již bylo uvedeno dříve v textu, na konferenci v roce 1925 byl předsedou konference zvolen Edvard Beneš.

O F. X. Hodačovi lze říci, že byl jedním ze stabilních prvků personálního substrátu orgánů MOP a jako takový zajištoval nejen personální, ale rovněž funkční kontinuitu této organizace. Právě v tomto ohledu lze mimo jiné chápat význam osobnosti v dějinách ve vztahu nejen ke státům či mezinárodním organizacím, ale rovněž k normotvorbě či aplikaci práva. ${ }^{174}$ Proto je zcela logické, že to byl právě F. X. Hodač, kdo byl již ve dvacátých letech na post místopředsedy Všeobecné konference MOP vybrán. Významnou pozicí bylo rovněž Hodačovo zařazení mezi ty funkcionáře Mezinárodní organizace práce, kteří přezkoumávali zprávy členských států MOP o provedení smluv, k nimž se tyto státy hlasováním a ratifikací zavázaly. F. X. Hodač se totiž stal nejprve náhradníkem ${ }^{175}$ a posléze členem komise ustavené podle čl. 408, tj. posuzující výroční zprávy členských států o opatření učiněných za účelem provedení úmluv, k nimž přistoupily. ${ }^{176}$

F. X. Hodač se ve druhé polovině dvacátých let na konferencích Mezinárodní organizace práce objevoval rovněž $\mathrm{v}$ jednotlivých komisích, vznikajících s ohledem na program konference. Tak v roce 1925, kdy byla Mezinárodní organizací práce schválena ${ }^{177}$ úmluva č. 18 týkající se odškodnění nemocí z povolání z roku $1925^{178}$ a úmluva č. 19 o rovnocenném nakládání s cizími a domácími zaměstnanci ve věci odškodnění pracovních úrazů 1925, jejíž ${ }^{179}$ čl. 1 př́slušníkům jiných členských států a členům jejich rodin při pracovních úrazech poskytoval stejné zacházení jako vlastním zaměstnancům, tedy zákaz diskriminace, a úmluva č. 20 o noční práci v pekárnách, 180 která však nebyla ČSR ratifikována, byl právě F. X. Hodač členem dvou klíčových komisí konference - komise pro úpravu odškodnění pracovních úrazů ${ }^{181}$ a komise pro úpravu noční práce v pekárnách. ${ }^{182}$

172 International Labour Conference. Eight Session. Geneva 1926. Vol. I. Geneva: International Labour Office, 1926, s. LXIII, International Labour Conference. Fourteenth Session. Geneva 1930. Vol. I. Geneva: International Labour Office, 1930, s. LVI a 39.

173 International Labour Conference. Eight Session. Geneva 1926. Vol. I. Geneva: International Labour Office, 1926, s. 14 a 277.

174 K významu osobnosti v dějinách viz např. BÁRTA, M. - KOVÁR̆, M. a kolektiv autorů. Lidé $a$ dějiny. K roli osobnosti v historii v multidisciplinární perspektivě. Praha: Academia, 2017, s. 19.

175 SKOCH, c. d., s. 117.

176 Viz např. International Labour Conference. Twelth Session. Geneva 1929. Vol. I. Geneva: International Labour Office, 1929, s. LXI nebo International Labour Conference. Fourteenth Session. Geneva 1930. Vol. I. Geneva: International Labour Office, 1930, s. 40.

177 KOLEKTIV AUTORŮ. Úmluvy Mezinárodní organizace práce ratifikované Českou republikou. I., s. 267.

178 Tamtéž, s. 267-269.

179 Tamtéž, s. 270-272.

180 [Online]. Dostupné na: https://www.ilo.org/dyn/normlex/en/f?p=1000:12000:::NO::.: [cit. 17. 07. 2019].

181 International Labour Conference. Seventh Session. Geneva 1925. Geneva: International Labour Office, 1925, s. LXXIX.

182 Tamtéž, s. LXXXVII. 
Ve stejné době začaly být vedeny rozsáhlé diskuze týkající se pracovní doby ve sklárnách. Protože šlo o odvětví v Československu zvláště rozvinuté, bylo i v zájmu československých zaměstnavatelů, aby dokázali svou přítomností formulovat stanoviska zaměstnavatelské kurie a ovlivnit výsledek jednání na konferencích. Zaměstnavatelům se nakonec podařilo prosadit názor o specifičnosti tohoto průmyslového sektoru, takže Mezinárodní organizace práce přijala ohledně této problematiky pouze dvě úmluvy - úmluvu č. 43 o pracovní době ve sklárnách na automaticky vyráběné tabulové sklo z r. $1934^{183}$ a úmluvu č. 49 o zkrácení pracovní doby ve sklárnách na výrobu lahví, ${ }^{184}$ jež byly nadto Československem ratifikovány a provedeny zákony ${ }^{185}$ až v září 1938 ve dnech bezprostředně předcházejících mnichovské tragédii, resp. jednání v Bad Godesbergu. ${ }^{186}$ Přesto se F. X. Hodač s ohledem na svrchu psané stal členem komise ohledně omezení práce ve sklářském provozu již v roce 1925.187

V roce 1926, kdy 8 . Všeobecná konference schválila vedle dalších konvencí1 ${ }^{188}$ taktéž úmluvu č. 21 o zjednodušení inspekce vystěhovalců na lodích 1926, ${ }^{189}$ zase F. X. Hodač zasedal v klíčové komisi pro zjednodušení inspekce imigrantů. ${ }^{190}$ Když byly v roce 1927 schváleny úmluvy MOP č. 24 a 25 o nemocenském pojištění zaměstnanců v průmyslu a v zemědělství, ${ }^{191} \mathrm{~F}$. X. Hodač byl opět jedním z důležitých hráčů na půdě Všeobecné konference, když byl členem komise pro nemocenské pojištění. ${ }^{192} \mathrm{~V}$ letech 1929 a 1930 byl F. X. Hodač členem komise k pracovní době placených zaměstnanců v obchodech a úřadech, ${ }^{193}$ a právě v roce 1930 Mezinárodní organizace práce přijala na své 14 . konferenci v Ženevě úmluvu č. 30 o pracovní době zaměstnanců v obchodě a na úrúadech. V roce 1930 byl rovněž F. X. Hodač členem komise pro pracovní dobu v dolech. ${ }^{194}$ Lze soudit, že se F. X. Hodač osvědčil i jako reprezentant Správní rady v dalších orgánech zřizovaných

183 KOLEKTIV AUTORŮ. Úmluvy Mezinárodní organizace práce ratifikované Českou republikou. I., s. $120-122$.

184 [Online]. Dostupné na: https://www.ilo.org/dyn/normlex/en/f?p=NORMLEXPUB:12000:0::NO:*.. [cit. 11. 07. 2019].

185 Zákony č. 353/1938 Sb. z. a n. a 354/1938 Sb. z. a n

186 Konkrétně se tak u obou smluv stalo 19. záři 1938. Viz KOLEKTIV AUTORŮ. Úmluvy Mezinárodní organizace práce ratifikované Českou republikou. I., s. 12.

187 International Labour Conference. Seventh Session. Geneva 1925. Geneva: International Labour Office, 1925, s. LXXXV.

188 Dalšími byla úmluva č. 22 o námořnických článcích dohod a č. 23 o repatriaci námořníků. [online]. Dostupné na: https://www.ilo.org/dyn/normlex/en/f?p=NORMLEXPUB:12000:0::NO::.. [cit. 09. 06. 2019].

189 KOLEKTIV AUTORŮ. Úmluvy Mezinárodni organizace práce ratifikované Českou republikou. I., s. 369-371. Úmluva byla Československem ratifikována dne 25. května 1928 a do vnitrostátního právního řádu provedena zákonem č. 181/1928 Sb. z. a n. Tamtéž, s. 12.

190 SKOCH, c. d., s. 116.

191 [Online]. Dostupné na: https://www.ilo.org/dyn/normlex/en/f?p=NORMLEXPUB:12000:0::NO::.. [cit. 09. 06. 2019].

192 International Labour Conference. Tenth Session. Geneva 1927. Geneva: International Labour Office, 1927, s. 26.

193 International Labour Conference. Twelth Session. Geneva 1929. Vol. I. Geneva: International Labour Office, 1929, s. LXIV, a International Labour Conference. Fourteenth Session. Geneva 1930. Vol. I. Geneva: International Labour Office, 1930, s. LIX.

194 International Labour Conference. Fourteenth Session. Geneva 1930. Vol. I. Geneva: International Labour Office, 1930, s. 40. 
Společností národů, nebot' v roce 1926 se znovu stal zástupcem Správní rady v přípravném výboru odzbrojovací konference snažící se navázat na Locarnské dohody. ${ }^{195}$

V rámci svých aktivit v Mezinárodní organizaci práce v letech 1925-1930 rovněž pokračovala v zaměstnavatelské sekci československé delegace na konferencích MOP kontinuitní personální politika, kdy na jedné straně Hodačovým stálým poradcem v MOP byl Josef Vaněk, který F. X. Hodače nahradil na postu generálního sekretáře Ústředního svazu československého průmyslu, když se František Xaver Hodač stal předsedou této stavovské organizace zaměstnavatelů, jednak za poradce byli vybíráni představitelé zaměstnavatelů a jejich svazů, kteří byli odborníky anebo činovníky v oblastech, o nichž konkrétní Všeobecná konference jednala. Současně po roce 1925 Československo nadále dbalo o zastoupení poradců z řad slovenských a německých podnikatelských elit. Je přitom třeba říci, že poradci nezastávali jen roli odborného zázemí delegáta. Při jednání jednotlivých komisí mohli poradci příslušného delegáta (v př́ípadě československých zaměstnavatelů tedy Františka Xavera Hodače) zastoupit. Mezi poradci F. X. Hodače se v průběhu druhé poloviny 20. let vystřídali např. zástupce německých podnikatelů Rudolf Fernegg, ${ }^{196}$ Jan Fiedler, tajemník Svazu sklářského průmyslu, když se jednalo o délce pracovní doby ve sklárnách, ${ }^{197}$ anebo Milto Kotrba, tajemník Ústředního svazu německých průmyslníků, ${ }^{198}$ který vystřídal Fernegga v roce 1927.

Ve stejném roce působil jako poradce F. X. Hodače na konferenci MOP František Kutscherka, náměstek Ústřední sociální pojišt’ovny, vrchní inspektor Vítkovických železáren v Moravské Ostravě a tajemník Svazu německých nemocenských pojišt’oven v Moravské Ostravě, ${ }^{199}$ nebot' byl projednáván návrh Správní rady Mezinárodní organizace práce na text úmluvy o nemocenském pojištění. V československých delegacích se v pozici poradců dále objevili např. Jan Dubický, místopředseda Ústředního svazu československých průmyslníků, ${ }^{200}$ Otto Brexl, zástupce německých zaměstnavatelů - generální tajemník Svazu německého průmyslu v ČSR, či Erwin Hexner, zástupce slovenských zaměstnavatelů, bilingvní odborník na obchodní právo, který psal povětšinou německy, občas rovněž česky, zejména se zaměřoval na ocelářský průmysl. Erwin Hexner zastupoval Československo později též na konferenci v Bretton Woods, kde vznikl Mezinárodní měnový fond. ${ }^{201}$

Jak již bylo řečeno, držel se F. X. Hodač při hlasování jednak zásady, že podporoval ingerenci státu do zastoupení zaměstnaneckých delegátů, jednak ve věcné rovině začal výrazněji vystupovat proti předkládaným návrhům úmluv Mezinárodní organizace prá-

195 International Labour Conference. Eight Session. Geneva 1926. Vol. II. Geneva: International Labour Office, 1926 , s. 68 a 70.

196 Viz výše. Ten se zúčastnil konferencí Mezinárodní organizace práce v letech 1924-1926 a 1928. Viz International Labour Conference. Seventh Session. Geneva 1925. Geneva: International Labour Office, 1926, s. LII, International Labour Conference. Eleventh Session. Geneva 1928. Vol. I. Geneva: International Labour Office, 1928, s. LX.

197 International Labour Conference. Seventh Session. Geneva 1925. Geneva: International Labour Office, 1925, s. LXXII.

198 SCHOENBAUM, E. O prováděni sociálniho pojištění u nás. Rozhovor ve schủzích Sociálního ústavu ČSR ve dnech 3. a 24. února a 3. a 10. března 1927. Praha: Lidová tiskárna Ant. Němec a spol., 1927, s. 83-88.

199 Ústřední sociální pojištovna 1926-1936. Praha: Ústřední sociální pojišt'ovna, 1936, s. 7, 11.

200 International Labour Conference. Eleventh Session. Geneva 1928. Vol. I. Geneva: International Labour Office, 1928, s. LX.

201 Viz Ervin Paul Hexner. [online]. Dostupné na: https://de.wikipedia.org/wiki/Ervin_Paul_Hexner. [cit. 12. 12. 2019]. 
ce. Povětšinou v první zmíněné kategorii hlasování náležel k vládně-zaměstnavatelské většině, která přehlasovala zástupce zaměstnanců. Při druhé kategorii hlasování - věcné - naopak patřil F. X. Hodač k významné menšině, které se ovšem obvykle nepodařilo přehlasovat většinu, která návrh konvencí předkládaných Správní radou, byt’ např̀. s jistými úpravami textu, schválila.

U hlasování o zástupcích zaměstnanců lze zmínit zejména každoroční ,zápas“ o připuštění italského korporativního delegáta zaměstnanců ${ }^{202}$ nebo hlasování v roce 1930, kdy F. X. Hodač společně s vládně-zaměstnavatelskou většinou prosadil přijetí litevského a švýcarského delegáta za zaměstnance. V prrípadě Litvy existoval podobný problém se zásadou autonomie tripartitních skupin jako v př́padě Itálie. Podle informací estonského představitele zaměstnanců a francouzského zaměstnaneckého delegáta litevský delegát Dinbergs reprezentoval organizace, které byly složeny ze zaměstnanců a zaměstnavatelů a existovaly z rozhodnutí litevské vlády. Proti tomu vystoupil zástupce litevské vlády, který nerozporoval podstatu uvedených informací, pouze nesouhlasil s jedním stř́pkem $\mathrm{z}$ předestřené faktografie, totiž $\mathrm{s}$ informací, že ve statistické ročence je příslušná osoba uvedena jako úředník ministerstva železnic o rok dříve, nikoliv v předmětném roce, kdy měl zastupovat zaměstnance. ${ }^{203}$ Tato drobná oprava stačila, aby tripartitní většina konference (včetně F. X. Hodače) přijala dotyčného delegáta jako představitele zaměstnanců.

V př́ípadě Švýcarska spočívala podstata sporu jinde. Záležela ve skutečnosti, že švýcarská vláda vybrala za jednoho z poradců švýcarského zaměstnaneckého delegáta představitele menších odborů a samotný delegát toto napadl, nebot’ se svým poradcem zjevně obtížně spolupracoval. Šlo vlastně o spor mezi odborovými organizacemi socialistické a křest’anské orientace. V tomto př́padě měli nejednoznačné stanovisko i samotní reprezentanti zaměstnanců. Zatímco francouzský zaměstnanecký člen konference se zastal švýcarského delegáta, nizozemský zástupce zaměstnanců uvedl, že různé organizace mohou spolupracovat a argumentoval i judikaturou Stálého soudu mezinárodní spravedlnosti, justičního orgánu Společnosti národů, který stanovil, že reprezentace má pocházet z různých odborových centrál. Francouzský delegát poté spor dostal do roviny kritiky povahy aktů aplikace práva, když odmítl obecnou (kvaziprecedenční) závaznost rozsudků Stálého soudu mezinárodní spravedlnosti, věren tehdejší francouzské civilistické koncepci kultu zákona, ${ }^{204}$

202 Viz International Labour Conference. Seventh Session. Geneva 1925. Geneva: International Labour Office, 1925, s. 77, International Labour Conference. Eight Session. Geneva 1926. Vol. I. Geneva: International Labour Office, 1926, s. 184, International Labour Conference. Tenth Session. Geneva 1927. Geneva: International Labour Office, 1927, s. 92, International Labour Conference. Eleventh Session. Geneva 1928. Vol. I. Geneva: International Labour Office, 1928, s. 160, International Labour Conference. Fourteenth Session. Geneva 1930. Vol. I. Geneva: International Labour Office, 1930.

203 International Labour Conference. Fourteenth Session. Geneva 1930. Vol. I. Geneva: International Labour Office, 1930, s. 242.

204 Např. lze zmínit tezi Jeana-Josepha Bugneta, že nezná pojem soukromého (občanského) práva, výlučně používá jen Code civil. Viz SELTENREICH, R a kol. Dějiny evropského kontinentálního práva. 3. upravené vydání. Praha: Leges, 2010, s. 738, též POKOL, B. The concept of law. The multi-layered legal system. Budapest: Rejtjel Ed., 2001, s. 21. [online]. Dostupné na: https://nbn-resolving.org/urn:nbn:de:0168-ssoar-67346. [cit. 02. 11. 2019]; nebo ALMEIDA RIBEIRO de, G. The Decline of Private Law. A Philosophical History of Liberal Legalism. Oxford: Hart Publishing, 2019, s. 184. 
že pramenem práva je pouze psané právo. ${ }^{205}$ I zde F. X. Hodač podpořil ingerenci vlády do výběru složení zaměstnanecké delegace. ${ }^{206}$

U hlasování o úmluvách např. hlasoval F. X. Hodač proti omezení noční práce v pekárnách ${ }^{207}$ nebo proti úmluvě o zkrácení pracovní doby ve sklárnách vyrábějících strojově. ${ }^{208}$ Naopak hlasoval pro úmluvu týkající se odškodnění nemocí z povolání z roku 1925.209 Rovněž hlasoval proti návrhu konvence na zjednodušení inspekce emigrantů na lodích v r. $1926^{210}$ a proti návrhu úmluvy o repatriaci námořníků. ${ }^{211} \mathrm{~F}$. X. Hodač také patřil mezi ty zaměstnavatele $\mathrm{v}$ Mezinárodní organizaci práce, kteří prosadili vedle práva sdruŽování zaměstnanců k prosazování jejich zájmů, ${ }^{212}$ též svobodu nesdružovat se a nebýt k takovému sdružování nuceni. ${ }^{213} \mathrm{Tj}$. z pohledu státovědného se zasloužil o to, aby se v mezinárodním pracovním právu objevil status negativus sui generis. ${ }^{214} \mathrm{~V}$ roce 1928 F. X. Hodač hlasoval proti úmluvě MOP č. 26 o systému stanovení minimální mzdy, jediné úmluvě, která byla toho roku přijata. V roce 1929 zase spolu se zástupci zaměstnavatelů na 12. konferenci Mezinárodní organizace práce usiloval o to, aby došlo k doplnění úmluvy č. 28 o ochraně před úrazy zaměstnanců při nakládání a vykládání lodí, a to tak, že by byla vyloučena vnitrostátní plavební doprava. Při tomto hlasování je zřetelná stopa zájmů československých zaměstnavatelů, nebot' Československo jinou než vnitrostátní plavební dopravu nemělo, takže by tím byli zaměstnavatelé ochráněni před ingerencí práva do jejich pracovněprávních vztahů.

Prosadit tuto revizi textu se však nepodařilo. Naproti tomu se F. X. Hodač vyslovil pro úmluvu č. 27 o označování váhy na velkých břemenech dopravovaných na lodích z roku 1929. ${ }^{215}$ Konečně hlasoval také při prvním čtení proti úmluvě MOP č. 31 o délce pracovní doby v dolech. ${ }^{216}$ Úmluva byla s konečnou platností přijata v roce $1931 .{ }^{217}$ František Xaver Hodač se z pozice československého delegáta zúčastnil Všeobecné konference

205 Ke sporu viz International Labour Conference. Fourteenth Session. Geneva 1930. Vol. I. Geneva: International Labour Office, 1930, s. 253-262.

206 Tamtéž, s. 263.

207 International Labour Conference. Seventh Session. Geneva 1925. Geneva: International Labour Office, 1925, s. 373 a 482.

208 Tamtéž, s. 414.

209 Tamtéž, s. 476 a 552.

210 International Labour Conference. Eight Session. Geneva 1926. Vol. I. Geneva: International Labour Office, 1926, s. 279.

211 International Labour Conference. Ninth Session. Geneva 1926. Vol. II. Geneva: International Labour Office, 1926, s. 347.

212 V Listině základních práv a svobod se týkají tohoto práva ustanovení čl. 20 a 27. Z úmluv Mezinárodní organizace práce zejména úmluva č. 18 z roku 1921 a úmluva č. 87 z roku 1948.

213 International Labour Conference. Tenth Session. Geneva 1927. Geneva: International Labour Office, 1927, s. 358.

214 Ke statutární teorii viz JELLINEK, G. System der subjektiven öffentlichen Rechte, 2. Aufl., Tübingen: J. C. B. Mohr, 1905, s. 86 a násl., nebo SACHS, M. Verfassungsrecht II. Grundrechte. 3. Auflage. BerlinHeidelberg: Springer Verlag, 2016, s. 44.

215 KOLEKTIV AUTORŮ. Úmluvy Mezinárodní organizace práce ratifikované Českou republikou. I., s. $372-373$.

216 International Labour Conference. Fourteenth Session. Geneva 1930. Vol. I. Geneva: International Labour Office, 1930, s. 398.

217 [Online]. Dostupné na: https://www.ilo.org/dyn/normlex/en/f?p=NORMLEXPUB:12000:0::NO::.: [cit. 09. 06. 2019]. 
Mezinárodní organizace práce za zaměstnavatele v r. 1931.218 Poté jej nahradil jeho dlouholetý poradce a generální sekretář Ústředního svazu československých průmyslníků Josef Vaněk. Jedním z důvodů této výměny byla též skutečnost, že F. X. Hodač dal po r. 1929 přednost svojí politické kariéře na domácí scéně.

\section{Závěr}

Lze souhlasit s konstatováním, že existence normativních hledisek, tj. představ a podoby právního řádu, je ,,vyvozena z dobově hegemonických představ o podstatě člověka, o jeho potřebách či morálních hodnotách, k nimž se má ,normální“ jednotlivec upínat“. ${ }^{219}$ Stanovisko o statické, a nejen od ostatních normativních systémů, nýbrž rovněž od evoluce společenských vztahů, hermeticky oddělené povaze práva jako normativního systému ${ }^{220}$ je legitimním, nicméně v řadě dílčích aspektů oprávněně diskutovaným předmětem diskurzu. Protože povahová, metodická i další svébytnost práva neznamená nutně jeho inkoherenci či dokonce imunitu vůči vnějším, mimoprávním vlivům a vzájemným prostupům. Právě naopak. Právo se snoubí nejen s dalšími normativními systémy, ale vyvěrá z ekonomicky vymezeného rámce, společenské situace, politických či jiných představ a zájmů, individuálního i kolektivního vědomí atp. Není osamocenou molekulou, nýbrž součástí komplexního fungování lidské společnosti již od vzniku prvních státních útvarů a možná i před jejich genezí.

Mezi oblasti, v nichž lze výrazněji vysledovat vliv dobové podmíněnosti práva, související nejen s hospodářskou úrovní společnosti, ale rovněž s dalšími mimoprávními faktory, náleží také pracovní právo. Existence, výstupy a aktivity Mezinárodní organizace práce jsou toho dobrým prríkladem. Předestřené poznatky z působení Františka Xavera Hodače v prvních pěti letech činnosti této odborné mezinárodní organizace, jejíž trvání bylo a je i v současnosti úzce spjato se soustavou mezinárodní bezpečnosti a snahou o konsenzuální řešení sporů, at' již v podobě Společnosti národů, jejíž byla MOP součástí, anebo Organizace spojených národů, u níž je MOP specializovanou agenturou „,věnující se rozvoji a propagaci norem pro vnitrostátní právní předpisy na ochranu a zlepšení pracovních podmínek a životních standardů ... rovněž poskytuje technickou pomoc v oblasti sociální politiky, administrativy a školení pracovní síly; podporuje spolupráci organizací a zemědělský průmysl; sestavuje statistiky práce a provádí výzkum sociálních problémů na úrovni mezinárodní soutěže, nezaměstnanosti a podzaměstnanosti, vztahu práce a průmyslu, technologické změny (včetně automatizace) a pomáhá chránit práva mezinárodních migrantů“ “221 pak představují tuto činnost nejen z pohledu jejího dílčího personálního elementu. Rovněž mohou ulehčit pochopení podoby stávajících mezinárodních standardů pracovního práva, dynamismu a trendů jeho vývoje 222 i výstupů - prameny mezinárodního

218 International Labour Conference. Fifteenth Session. Geneva 1931. Vol. I. Geneva: International Labour Office, 1931, s. XLVIII.

219 RÁKOSNÍK, c. d., s. 9.

220 Tuto koncepci zastávala např. ryzí nauka právní.

221 [Online]. Dostupné na: http://ebozp.vubp.cz/wiki/index.php/Mezininárodní_organizace_práce. [cit. 18. 12. 2019].

222 Když v roce 1919 na první konferenci Mezinárodní organizace práce, kdy československou delegaci vedl tehdejší ministr zahraničních věcí Edvard Beneš, byla tématem osmihodinová pracovní doba, po cca sto letech na 107. zasedání MOP (28. 5. - 8. 6. 2018), kdy českou delegaci reprezentoval na prvém místě náměstek Ministerstva práce a sociálních věcí Petr Hůrka, se debata soustředila na „násilí a obtěžování na 
pracovního práva, mutatis mutandis prameny práva jako celku. Také ukazují, že geneze a existence Mezinárodní organizace práce má z hlediska liberální a sociální demokracie své opodstatnění, nebot' tato organizace od r. 1919 dodnes přináší tříbení názorů a výsledky směřující ke standardizaci a kompromisnímu hledání právních východisek z možných pracovních sporů bez ohledu na dějinné epochy a těžkosti jimiž svět procházel.

Současně se analýza získaných poznatků snaží z právněhistorické perspektivy prozkoumat poněkud opomíjenou část pracovní poutě Františka Xavera Hodače, totiž jeho působení v Mezinárodní organizaci práce, a alespoň dílem tak dotváŕí mozaiku bohatého a naplněného života této významné, byt' snad poněkud kontroverzní osobnosti. Bez zajímavosti nemusí být ani skutečnost, že František Xaver Hodač s filozofickým a obecně právnickým vzděláním významným způsobem ovlivnil pracovní právo a tím zprostředkovaně i národní hospodářství v Československu. I to je ukázka tentokrát konceptualizační časové podmíněnosti, která kuprríkladu reflektuje rozdíl oproti v postmoderní době preferovanému formování úzce specializovaných odborníků bez všeobecného rozhledu, teoretického uvažování a abstrakce jako nadčasové nezbytnosti. ${ }^{223}$

Konečně sledování působení Františka Xavera Hodače v Mezinárodní organizaci práce ukazuje, jak nezanedbatelný význam hrála Československá republika při vytváření základů moderního pracovního práva platného nejen na jejím území, nýbrž alespoň zčásti v právních řádech pokrývajících rozsáhlá teritoria světa. Taktéž představuje sondu do československého ovlivňování fungování Společnosti národů v tomto směru. Na druhou stranu prezentuje, že konečná podoba živého práva může být formována stejně dobře koncepcí chápající právo jako ars boni et aequi ${ }^{224}$ starověkých římských juristů, rovněž jako projevem utilitárních a dílčích zájmů, a nezřídka dokonce obojího, prolínajícího se ve vzácné jednotě. Historie má nejen zprostředkovací, ale rovněž noetickou, poznávací funkci, ${ }^{225}$ a to rovněž ohledně kořenů ale i platné podoby právního řádu. Starověcí Římané zahrnuli oboje pod pojem delecto, delectare. ${ }^{226}$ Hodnocení působení Františka Xavera Hodače v Mezinárodní organizaci práce, podobně jako u dalších významných osob, lze uzavřít citátem vypůjčeným z pozdně republikánského Říma, od Marka Tullia Cicerona, jehož citát tento článek zahájil: ,Život nikdy nebyl př́liš krátký pro toho, kdo vykonal povinnosti diktované ctností."'227

pracovišti, $\mathrm{k}$ roli Mezinárodní organizace práce $\mathrm{v}$ oblasti rozvojové spolupráce a ke strategickým cílům sociálního dialogu v rámci tripartity“. Viz Česká republika na 107. zasedání Mezinárodní organizace práce. [online]. Dostupné na: https://www.mzv.cz/mission.geneva/cz/udrzitelny_rozvoj/mezinarodni_organizace_prace_ceska_republika_na_107_zasedani.html. [cit. 18.12. 2019].

223 Ke kritice př́lišné specializace a opouštění znalosti kontextu, tj. širšího rozhledu, které se objevovaly již v časech minulých, viz např. MARX, K. Das Elend der Philosophie. Marx-Engels Werke. Berlin: Dietz Verlag, 1972, s. 157. [online]. Dostupné na: http://www.mlwerke.de/me/me04/me04_125.htm\#K2_2 [cit. 11. 06. 2019]; a Fachidiot. [online]. Dostupné na: https://de.wikipedia.org/wiki/Fachidiot. [cit. 11. 06. 2019]; nebo LIESSMANN, K. P. Teorie nevzdělanosti. Praha: Academia, 2009.

224 Ulp. D. 1, 1, 1 pr. Viz SKŘEJPEK, M. (ed.). Digesta seu Pandectae/Digesta neboli Pandekty. Fragmenta selecta / Vybrané části. Tomus I. Liber I-XV / Svazek I. kniha I-XV. Praha: Karolinum, 2015, s. 67.

225 BENEŠ, Z. Úvod. In: SEMOTANOVÁ, E. a kol. Česko. Ottưv historický atlas. 3. aktualizované vydání. Praha: Ottovo nakl. s.r.o., 2017, s. 9.

226 Tamtéž.

227 CICERO, M. T. Tuskulské rozhovory. Praha: Svoboda, 1976, s. 81. 